\title{
Siliciclastic input into Upper Cenomanian synorogenic sediments of the High-Tatric Unit, Central Western Carpathians (Tatra Mountains); petrography, geochemistry and provenance
}

\author{
Anna WOLSKA ${ }^{1, *}$, Krzysztof BAূK $^{1}$ and Marta BAKK ${ }^{2}$ \\ 1 Pedagogical University of Cracow, Institute of Geography, Podchorążych 2, 30-084 Kraków, Poland \\ 2 AGH University of Science and Technology, Faculty of Geology, Geophysics and Environmental Protection, \\ Al. A. Mickiewicza 30, 30-059 Kraków, Poland
}

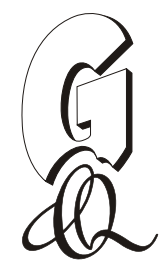

\begin{abstract}
Wolska, A., Bąk, K., Bąk, M., 2016. Siliciclastic input into Upper Cenomanian synorogenic sediments of the High-Tatric Unit, Central Western Carpathians (Tatra Mountains); petrography, geochemistry and provenance. Geological Quarterly, 60 (4): 919-934, doi: 10.7306/gq.1316
\end{abstract}

\begin{abstract}
The Upper Cenomanian mixed siliciclastic-carbonate succession of the High-Tatric Unit was deposited during the initial stage of basinal closing of the Tatric area, part of the Zliechov (Križna) Basin (Inner Carpathian domain). As a result of tectonic activity taking place at the northern Veporic margin, pulses of siliciclastic input interrupted marine carbonate sedimentation. The siliciclastic material, part of the Zabijak Formation, has been studied along two sections (Pisana Gully and Zdziarski Gully) in the Western Tatra Mountains. Microfacies, petrographic and geochemical analyses reveal a variability of siliciclastic material composed of various types of granitoids and medium- or high-grade metamorphic rocks, with schists and gneisses. Such interpretation is confirmed by the results of elemental chemical analyses, in which immobile trace elements, such as REE, Th, $\mathrm{Cr}$, Co, Zr, and $\mathrm{Y}$ were used as indices for sediment provenance. The parent rocks sustained moderate to intense chemical weathering, documented by chemical weathering indices (CIA, PIA, CIW, R). The weathering occurred in a humid climate with relatively high precipitation that caused strong leaching of particles. Chemical indices related to sorting processes suggest that the recycling of the source material was a minor significance. The siliciclastic input displays a waning upward tendency in the sections, which can be associated with diminishing of the source area by gradual inland progradation of a carbonate platform, caused by a global sea level rise during the Late Cenomanian.
\end{abstract}

Key words: petrography, geochemistry, Upper Cenomanian, Zabijak Formation, High-Tatric Units, Central Western Carpathians.

\section{INTRODUCTION}

During the Albian, convergence between the margins of Gondwana and Laurasia started, resulting in destruction of former basinal systems belonging to the Penninic Ocean (Voigt et al., 2008). Carbonate platforms lying on the southern edge of the Penninic Ocean in the Carpathian domain, including those on the Tatric area, were covered mainly by calcareous-rich mud (Vašíček et al., 1994). During the Late Cenomanian, turbidite sedimentation gradually replaced the hemipelagic calcareous sedimentation in the Tatric area (Bak and Bak, 2013). It was the initial stage of the Zliechov (Križna) Basin closing that lasted through the Turonian-?Coniacian, resulting in folding and thrusting of the High- and Sub-Tatric nappes (Jurewicz, 2005 and references therein).

* Corresponding author, e-mail: awolska@up.krakow.pl

Received: August 3, 2015; accepted: August 31, 2016; first published online: September 22, 2016
The final stage of marine sedimentation in the Tatric area, with deposition of siliciclastic material is a subject of this paper. The material studied belongs to the autochthonous succession of the High-Tatric Units (Central Western Carpathians), outcropped in the Tatra Mountains (Fig. 1A, B; Passendorfer, $1930,1978)$. The aim of this paper is to characterize these sediments and to detect their provenance based on their petrographic, microfacial and geochemical characteristics.

\section{GEOLOGICAL SETTING}

The described siliciclastics coming from mixed calcareous-siliciclastic sediments are the youngest marine sediments of the Tatric successions. They have been distinguished as the Pisana Member of the Zabijak Formation, the topmost lithostratigraphic unit in the High-Tatric Units (Fig. 2; Lefeld, 1985; Krajewski, 2003). These sediments are exposed within the para-autochthonous unit occurring in the Tatra Mountains, which is part of a tectonic unit called Tatricum. This unit represents an upper crustal thrust sheet of the Central Western Carpathians comprising the pre-Alpine crystalline basement and the Late Paleozoic-Mesozoic sedimentary cover (Plašienka, 1999, 2003). 

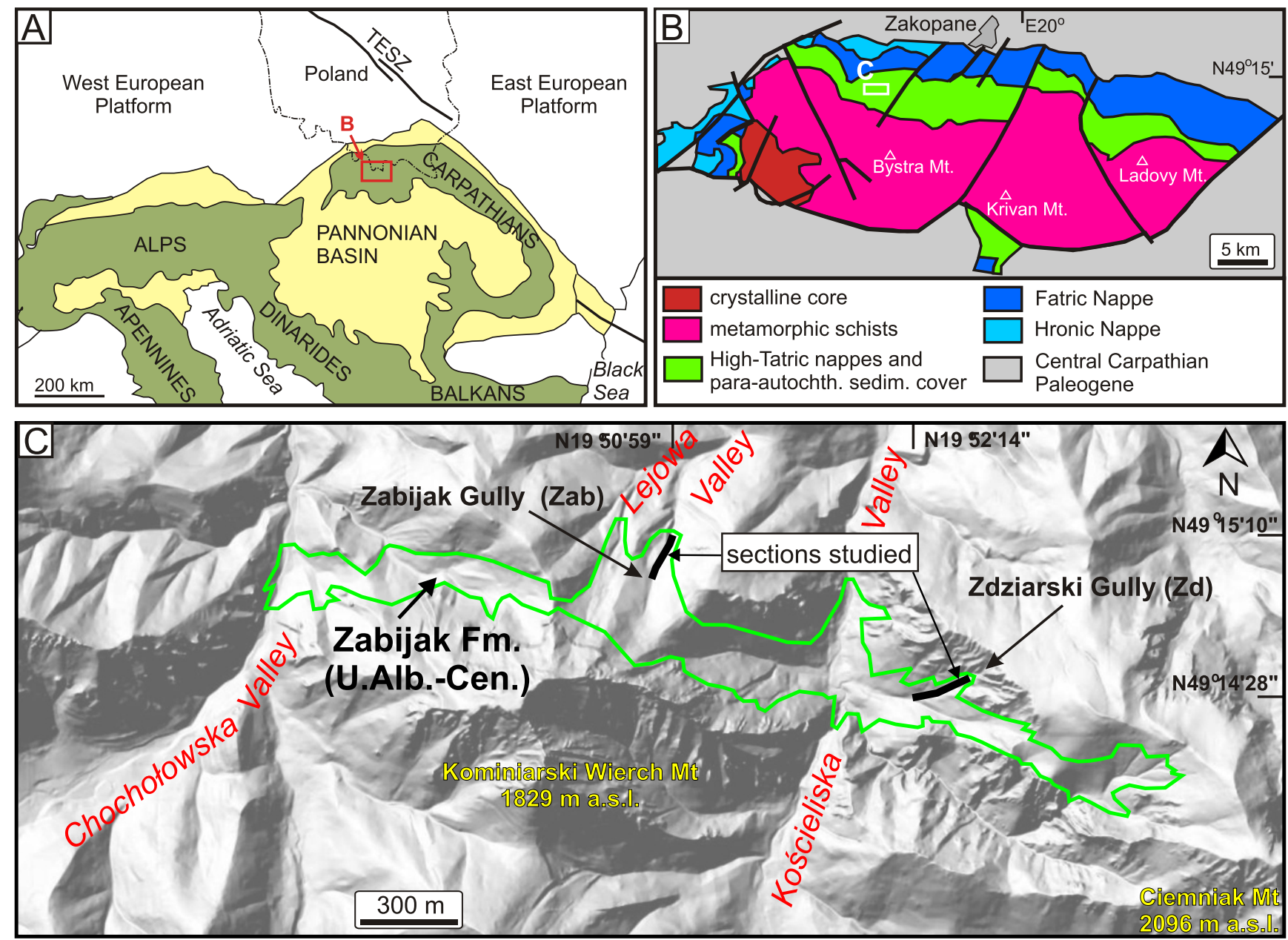

Fig. 1A - the Carpathians on the background of simplified geological map of Alpine orogens and their foreland; B - simplified geological map of the Tatra Mountains with the location of the study area (map after Bac-Moszaszwili et al., 1979); C - location of the studied sections (black lines) in the Tatra Mountains

Relief map after www.geoportal.gov.pl; GPS coordinates are related to the base (Zabijak Gully) and the top (Zdziarski Gully) of the sections

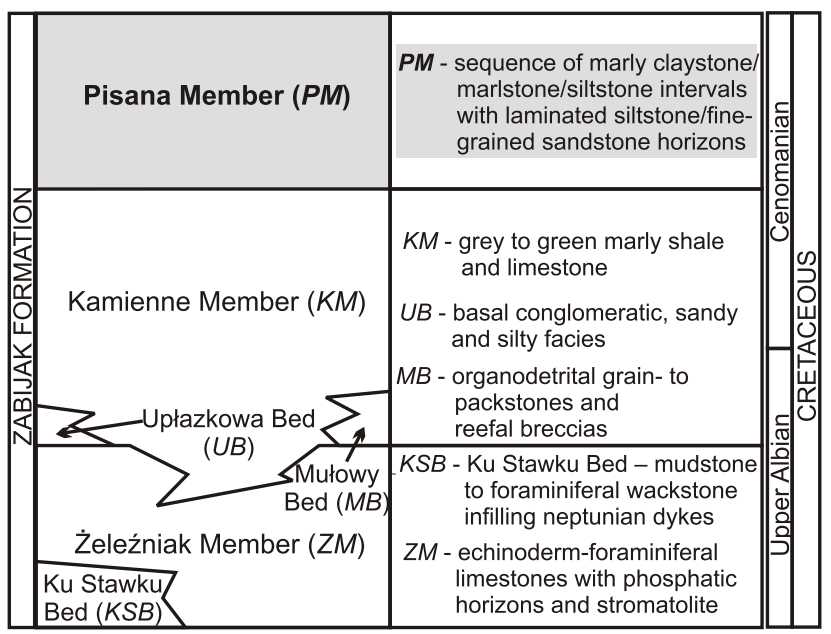

Fig. 2. Lithostratigraphy of the Upper Albian-Cenomanian sediments (Zabijak Formation) in the Polish part of the High-Tatric Units, Tatra Mountains (Krajewski, 2003)

Unit studied highlighted in grey
The most characteristic feature of the Pisana Member is the occurrence of grey thin-bedded, laminated siltstones and fine-grained sandstones with calcareous cement, which form four packages, 6-20 m thick (Fig. 3; Krajewski, 2003). The sedimentary features of these sediments suggest their rhythmic deposition from low-density and low-velocity turbidity currents in a hemipelagic basinal environment (Krajewski, 2003; Bakk et al., 2016). The total thickness of the Pisana Member is difficult to measure due to tectonic deformation related to thrusting processes. According to Krajewski (2003), the maximum thickness is approximately $170 \mathrm{~m}$, however, tectonic repetitions are very likely.

The age of sediments belonging to the Pisana Member has been assigned in the study area based on the foraminiferal, radiolarian and carbon isotopic studies (Bak and Bak, 2013; Bakk et al., 2016) as the Late Cenomanian. Their deposition took place during global sea level fluctuations that occurred at ca. 95.5 Ma, comparing with the Haq (2014) eustatic curve. The upper boundary of the Pisana Member is defined along the overthrust surface of the High- or Subtatric units.

Micropalaeontological studies show that the sea-floor was located at upper bathyal depths and the water column was poorly oxygenated (Bakk et al., 2016). The scarcity of marine 


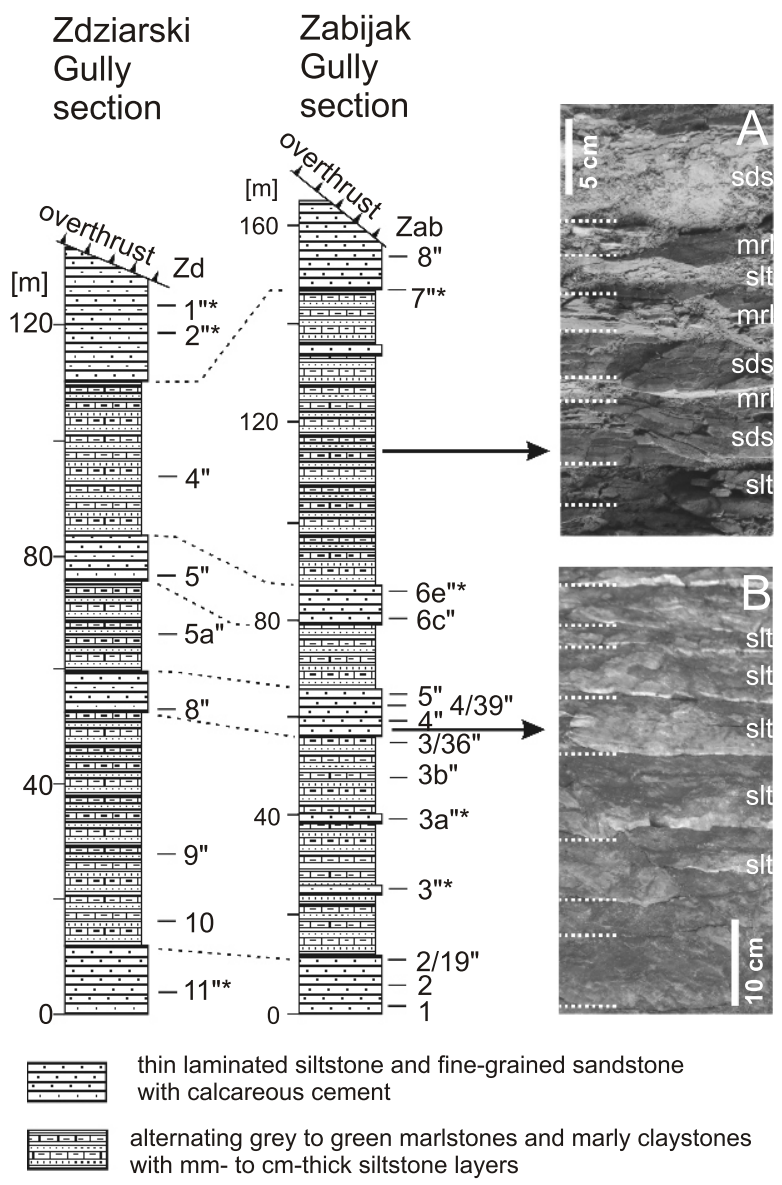

Fig. 3. Lithological logs of the Upper Cenomanian Pisana Member (Zabijak Formation) at the Zabijak Gully and Zdziarski Gully sections (High-Tatric Units, Tatra Mountains; after Krajewski, 2003) with the position of samples and photographs of two subfacies: A - sandstone/ siltsto$\mathrm{ne} / \mathrm{marlstone} \mathrm{(sds/s/t/mrl)} \mathrm{and} \mathrm{B} \mathrm{-} \mathrm{laminated} \mathrm{siltstone} \mathrm{(slt)}$

" - samples for microfacies analysis; * - samples for bulk chemical analysis

fossils in redeposited material and features of carbonate lithoclasts suggest very low productivity in the nearshore surface water, most probably due to a low-density hyposaline cap as surface runoff from the southern margin of the Zliechov (Križna) Basin. In turn, the intrabasinal carbonate microfossils indicate moderate primary productivity with rare periods of enhanced upwelling that brought nutrient-rich oceanic water, which reached the northern edge of the Tatric area (Bakk et al., 2016).

\section{MATERIAL AND METHODS}

Two exposures of the Pisana Member were studied in the Polish part of the Tatra Mountains. Both occur along gullies (Zabijak Gully and Zdziarski Gully) crossing the Upper Albian-Cenomanian strata in the Lejowa and Kościeliska drainage basins (Fig. 1C). The outcrops of the Pisana Member in the Zabijak Gully, a tributary of the Lejowa Valley, occur on both slopes of the gully. The sediments studied represent the youngest part of the Pisana Member, correlated to the Late
Cenomanian interval preceding the Oceanic Anoxic Event 2 sediments (Fig. 3; Bak et al., 2016). The siliciclastics from this section contain four thick packages (6-20 m thick) of thin-bedded (up to $10 \mathrm{~cm}$ ), laminated siltstone (Fig. 3B) and sandstone layers. They occur in a sequence of alternating grey to green marlstones and marly claystones that contain from $\mathrm{mm}$ - to $\mathrm{cm}$-thick siltstone layers (Fig. 3A). Fine-grained thin-bedded $(5-10 \mathrm{~cm})$ sandstone layers are rare; occasionally, thicker beds reach $60 \mathrm{~cm}$. The outcrops of the Pisana Member are scarce in the Zdziarski Gully, however, four packages of siltstone and sandstone layers (from 6 to $15 \mathrm{~m}$ thick), resistant to weathering and erosion, are well-recognizable (Fig. 3). Due to similar tectonic position of the Zdziarski and Pisana sections, and relatively short distances between them $(\sim 1 \mathrm{~km})$, these four thick packages of siltstone and sandstone layers may represent the same lithologic horizons (Fig. 3), as was earlier suggested by Krajewski (2003).

Field sedimentological observations, microscopic analyses including mineralogy and petrography of layers that contain siliciclastics, and geochemical analyses were the basis of the present study.

Analysis of the layers was performed on 23 samples (Fig. 3) using a Nicon YM-EPI Eclipse E600POL optical microscope. The microfacies composition of these samples was determined in 18 thin-sections (Fig. 3) based on visual estimation of percentage after Folk (1951) and Terry and Chilingar (1955). The inventory of mineral components was observed millimetre by millimetre under light microscope in magnification $80 \mathrm{x}$. Thicknesses of laminae, usually poorly separated, vary from 0.2 to $3 \mathrm{~mm}$ depending on changes in their lithology. The laminae were distinguished on the basis of vertical distribution of grains and classified into three fractions.

The modal mineralogy of the sediment were obtained by counting at least 700 points with a ZEISS automatic counter in each thin-section. Rock framework composition (modal analysis) was quantified using the point-counter method described by Dickinson (1985). In contrast to the Gazzi-Dickinson method (Ingersoll et al., 1984), minerals $>63 \mu \mathrm{m}$ within lithoclasts were counted as rock-forming minerals of the lithoclast composition (Decker and Helmold, 1985).

The JEOL 5410 electron microscope equipped with an energy spectrometer Voyager 3100 (NORAN) was used in microprobe chemical analyses of selected rock-forming minerals. The measurements were carried out using a spot method.

Seven samples of siltstone and sandstone layers (Zab-3, 3a, 6c, 7; Zd-1, 2, 11; Fig. 3) were analysed for the concentration of major and minor elements at the Bureau Veritas Minerals Laboratories, Vancouver, Canada. Total abundances of the major oxides and several minor elements were analysed by ICP-emission spectrometry following a lithium metaborate/tetraborate fusion and dilute nitric acid digestion. Loss on ignition (LOI) was determined by weight difference after ignition at $1000^{\circ} \mathrm{C}$ for $>2 \mathrm{~h}$. Rare earth and refractory elements were determined by ICP mass spectrometry after fusion with a mixture of lithium metaborate/tetraborate fusion and nitric acid digestion. Moreover, separate $0.5 \mathrm{~g}$ samples were digested in Aqua Regia and analysed by ICP mass spectrometry to report the precious and base metals. Detection limits range from 0.002 to $0.01 \mathrm{wt}$ \% for major oxides, from 0.1 to $20 \mathrm{ppm}$ for trace elements, and from 0.01 to $0.1 \mathrm{ppm}$ for the rare earth elements. The CANMET and USGS certified reference materials were used as monitors of data quality. The trace element and REE were normalized using chondrite values (Thompson, 1982), PAAS values and UCC values (Taylor and McLennan, 1985).

The total calcium carbonate content of seven samples was measured using the Scheibler method, in which $\mathrm{CaCO}_{3}$ content 
is calculated from the volume of emitted carbon dioxide, as a consequence of reaction of the powdered rock sample $(1 \mathrm{~g})$ with $10 \%$ hydrochloric acid. The data have been corrected in relation to air temperature and atmospheric pressure.

The residual rock samples used in petrographic studies, and microfacies slides are housed at the Institute of Geography, Pedagogical University of Cracow (collection of K. Bąk).

\section{RESULTS}

\section{MICROFACIES OF SILICICLASTIC-BEARING SEDIMENTS}

Siliciclastic material has been studied in beds containing an admixture of siliciclastic and calcareous grains from very fine sand up to clay fractions (Fig. 4A). Macroscopically, the rocks are represented by sandy limestones, calcareous sandstones, marly siltstones and silty marlstones. According to Folk (1980) classification, these sediments belong generally to arenites and mudrocks. Arenites represent calcilithites from the litharenite group, which contain $>30 \%$ of calcareous grains, and have immature texture. Mudrocks are represented by siltstones, mudstones and claystones. Based on their mineral composition, siltstones and mudstones are of orthoquartzite through calcilithite types, as they contain predominately quartz grains and up to $60 \%$ of calcareous grains admixture. Some of the mudstones and clay- stones are of phyllarenite type, as they contain quartz grains in the silt fraction and abundant white fine-grained micas.

Siliciclastic grains in arenites as well as in mudrocks constitute the grain framework or they consist of matrix components (Fig. 4B-D). These are predominately quartz grains, other minerals and various types of lithoclasts (Fig. 4D). Their total content is high in arenites, mudstones and siltstones (up to 60\%), but they display a general trend of decreasing upward the section (Fig. 5). The content of calcareous grains in siliciclastic-bearing sediments show an opposite trend, however, their maximum content in all fractions reach $80 \%$ of total amount (Fig. 5).

In arenite laminas, quartz grains are oriented chaotically. Sharp contacts between arenite and silt laminas are commonly visible (Fig. 6B). Carbonate sparitic/micritic cement of basal type is present (Fig. 6C).

Siliciclastic grains contain mostly quartz that may constitute even up to $90 \%$ of a single sample view (Fig. 5). Quartz grains are both angular and rounded. Rounded quartz grains are less common in the sandy fraction, but their content is significantly higher in mudstones and siltstones. The opposite trend is observed for angular quartz, with a much higher content in the sandy fraction, up to $95 \%$. Mica flakes are also common, up to $40 \%$, especially in siltstones and claystones.

Redeposited calcareous grains are also associated with terrigenous particles (see also in Bakk et al., 2016). These are in the very fine sandy to silty fractions, usually poorly to moderately rounded. Calcareous grains contain predominately mi-
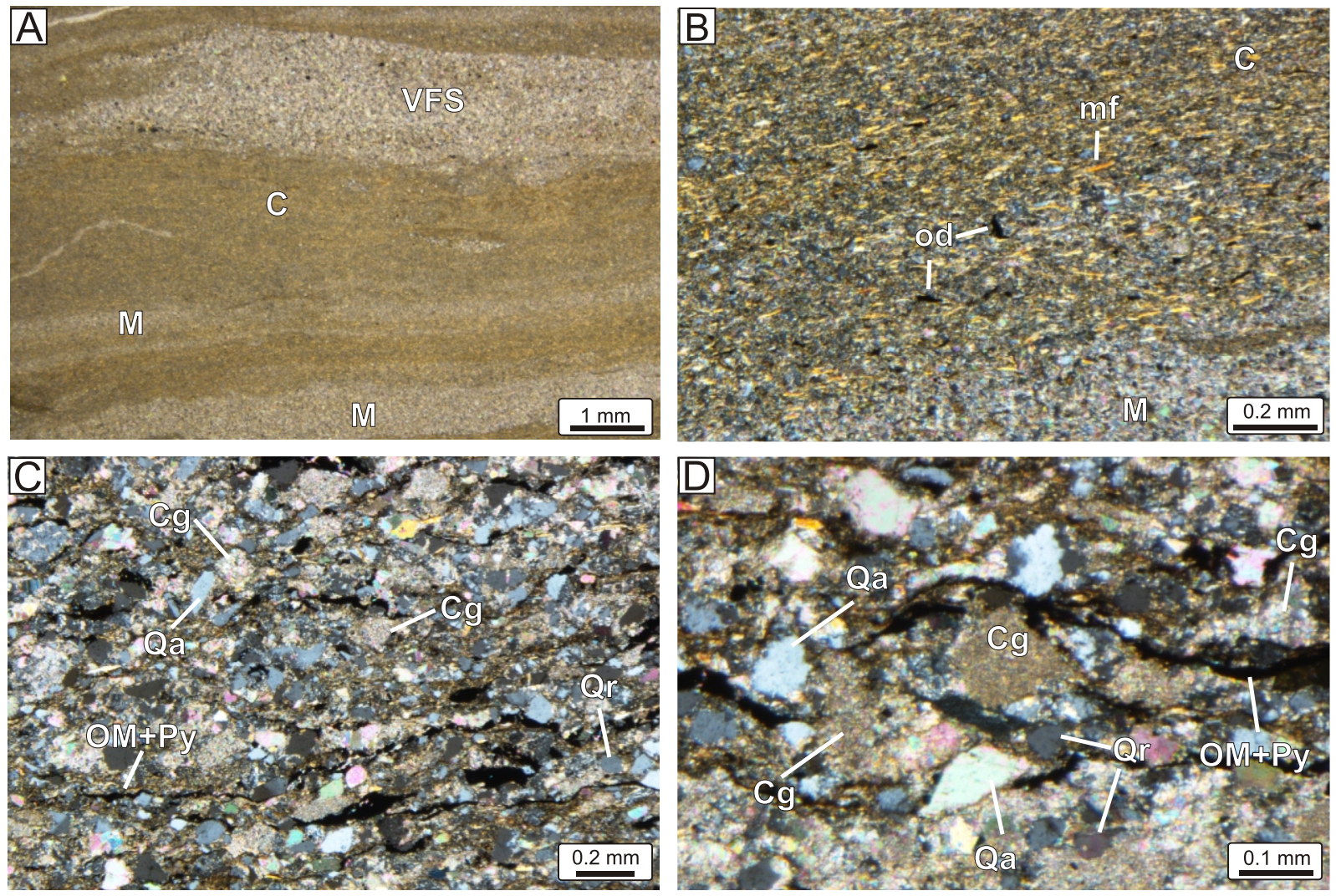

Fig. 4. Microfacies and components in siltstones and sandstones from the Upper Cenomanian sediments of the Pisana Member, High-Tatric Units, Tatra Mountains

A - general view, relation and thickness of very fine-grained sandstone (VFS), mudstone (M) and claystone (C), sample Zab2; B - gradual transition from mudstone to claystone with increasing content of mica flakes ( $\mathrm{mf}$ ) and organic detritus (od), sample Zab2; C - components of very fine-grained sandstone, sample Zab2/19: rounded quartz (Qr), angular quartz (Qa), calcareous grains $(\mathrm{Cg})$, and seams of organic matter with pyrite framboids (OM+Py); D - close-up view of sample Zab2/19, showing more details of detrital grains and high ratio of calcareous to siliciclastic grains, abbreviations as in Figure $\mathrm{C}$ 


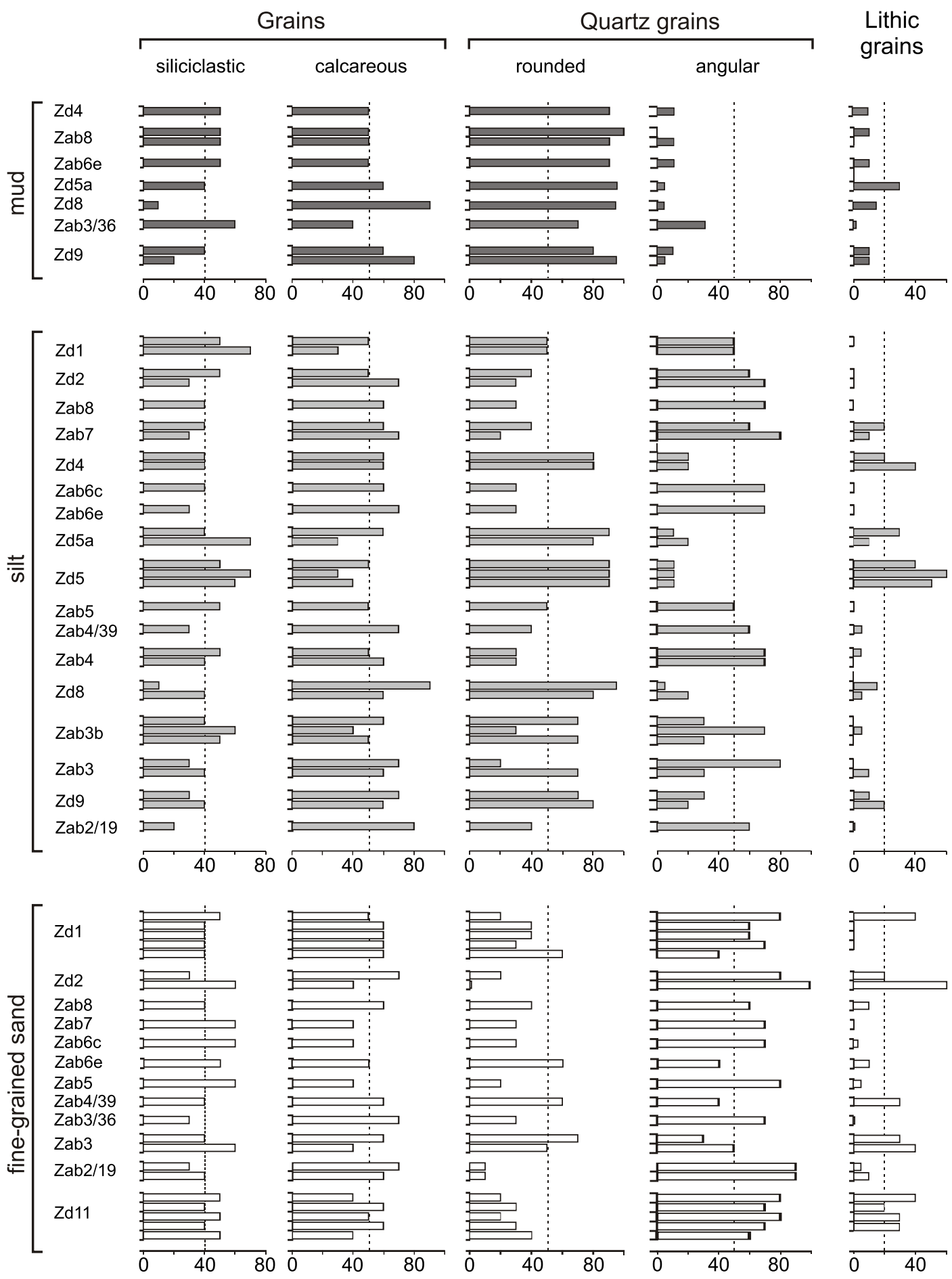

Fig. 5. Percentage content of main mineral constituents of siliciclastic-bearing Upper Cenomanian sediments of the Pisana Member, High-Tatric Unit, Tatra Mountains, based on thin-section analyses of particular laminae representing various fractions

Total percentage content of siliciclastic and calcareous grains - 100\%; total percentage content of rounded and angular quartz grains $-100 \%$; content of lithic grains as percentage of siliciclastic grains; order of samples was compiled based on the position of thick packages of thin-bedded laminated siltstone in both sections - see Figure 3 

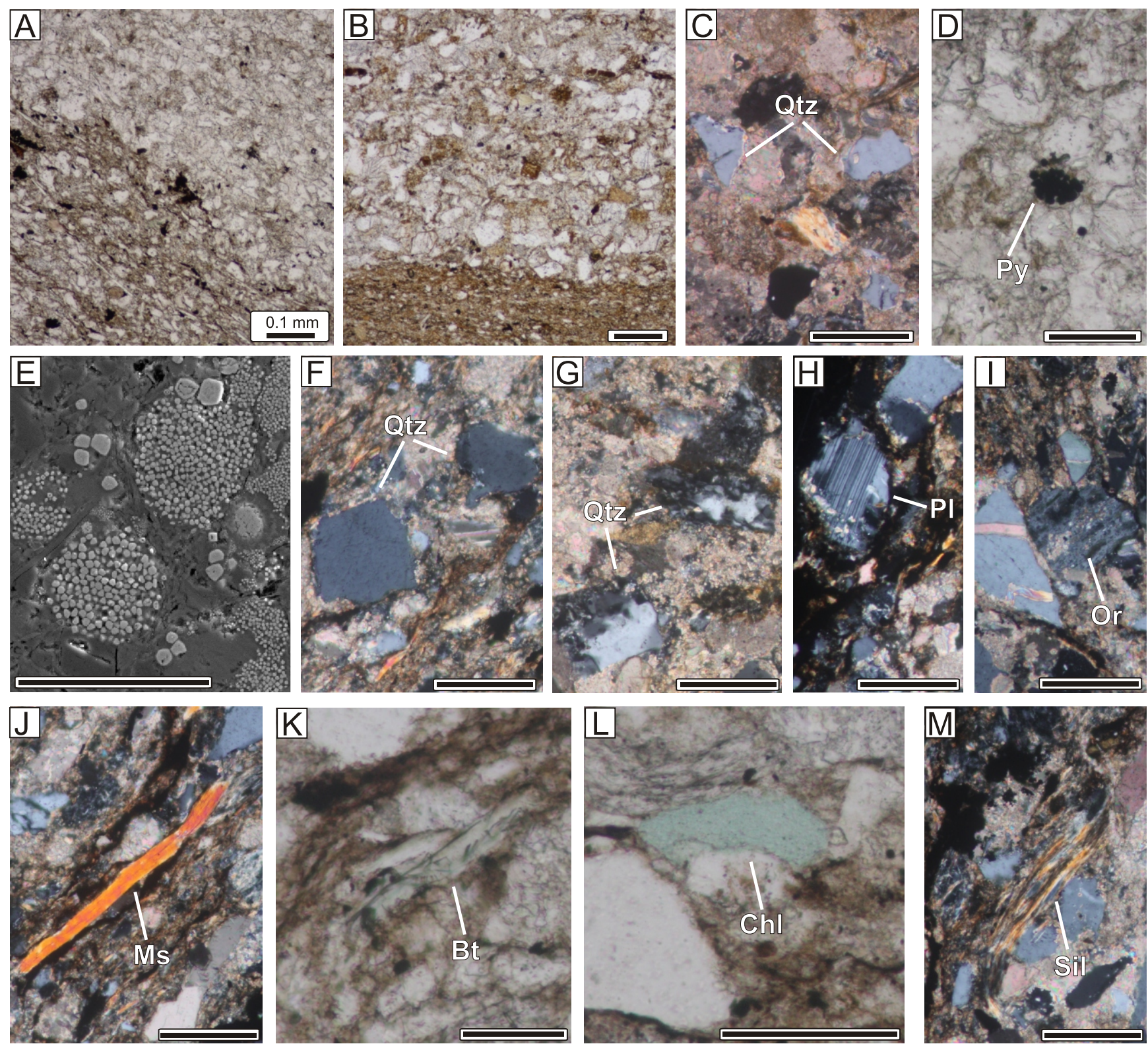

Fig. 6. Microphotographs of mineral grains and lithoclasts in siltstones and sandstones from the Upper Cenomanian sediments of the Pisana Member, High-Tatric Unit, Tatra Mountains

A - white mica flakes directionally oriented in silty laminae, sample Zab7; B - sharp contact between silty and sandy laminae, sample Zab4; C - corroded quartz grains by the carbonate basal cement, sample Zab4/39; D, E - framboidal pyrite in seams of organic matter (D - sample Zab7, E - sample Zab3a); F - quartz grains (Qtz) displaying normal extinction, sample Zab2/19; G - mosaic quartz grains (Qtz), sample Zd2; $\mathbf{H}$ - plagioclase grain (PI) with multiple twinning, sample Zab2/19; I-altered orthoclase grain (Or), sample Zab2/19; $\mathbf{J}$ - framework with mica flake (Ms), sample Zab2/19; K - altered biotite (Bt) with sagenitic inner texture, sample Zab2/19; L - chlorite grain (Chl), sample Zab2/19; $\mathbf{M}$ fibrolite sillimanite grain (Sil), sample Zab2/19

crites and sparites, without biogenic admixture, which comprises almost $50 \%$ of total amount. Calcareous benthic foraminifers as redeposited calcareous grains do not surpass $20 \%$. Mollusc shells are $<1 \%$. Dolomite crystals, sometimes rounded, occur also as redeposited grains. Their content does not exceed two percent.

The distribution of angular quartz and calcareous grains along the section studied is bimodal (Fig. 5).
PETROGRAPHY OF SILICICLASTICS FROM SILICICLASTIC-BEARING SEDIMENTS

The siliciclastic components from the sediments studied are dominated by quartz grains in the sand fraction, ranging from $0.063 \mathrm{~mm}$ to $0.21 \mathrm{~mm}$ in size. Quartz grains are angular to rounded in outer outline (Fig. 4C). Rounded quartz prevail in the fraction $<0.2 \mathrm{~mm}$. Their distribution in the Zabijak Gully section is bimodal (Fig. 5). The angular quartz content is uniform along the sections, ranging from 40 to $50 \%$. Most of the 
quartz grains display normal extinction (Fig. 6F) and mosaic texture (Fig. 6G). Other mineral grains are less common. Together with lithoclasts, their average abundance is $10 \%$, however, in some samples (Zd1, Zd2, Zab7, Zab4/39), the content of lithoclasts and minerals, excluding quartz, is up to $23 \%$. This content reaches the maximum value in sample $\mathrm{Zd} 2$, that is $60 \%$ (Fig. 5). Mineral grains and lithoclasts are moderately sorted and exhibit various rounding classes, from angular through subangular to subrounded.

Feldspar grains, i.e. plagioclase (Fig. $6 \mathrm{H}$ ) and orthoclase (Fig. 6I), flakes of white mica (Fig. 6J), altered biotite with sagenitic structure (Fig. 6K), chlorite (Fig. 6L), and sillimanite fibrolite aggregates (Fig. 6M) are very rare. Lithoclasts are represented by medium-grade metamorphic rocks, including gneisses (Fig. 7A) and schists (Fig. 7B), hydrothermally altered granites with kaolinitized feldspars (Fig. 7C), cataclastic granites (Fig. 7D), slates (Fig. 7E), and siderites (Fig. 7F). Additionally, grains of heavy minerals have been found in these sediments, including tourmaline (Fig. 7G), rutile (Fig. 7H) and zircon (Fig. $7 \mathrm{I}$ ). In laminas of the silt fraction, framboidal pyrite (oxygenated to various degrees) was observed (Fig. 6D, E).
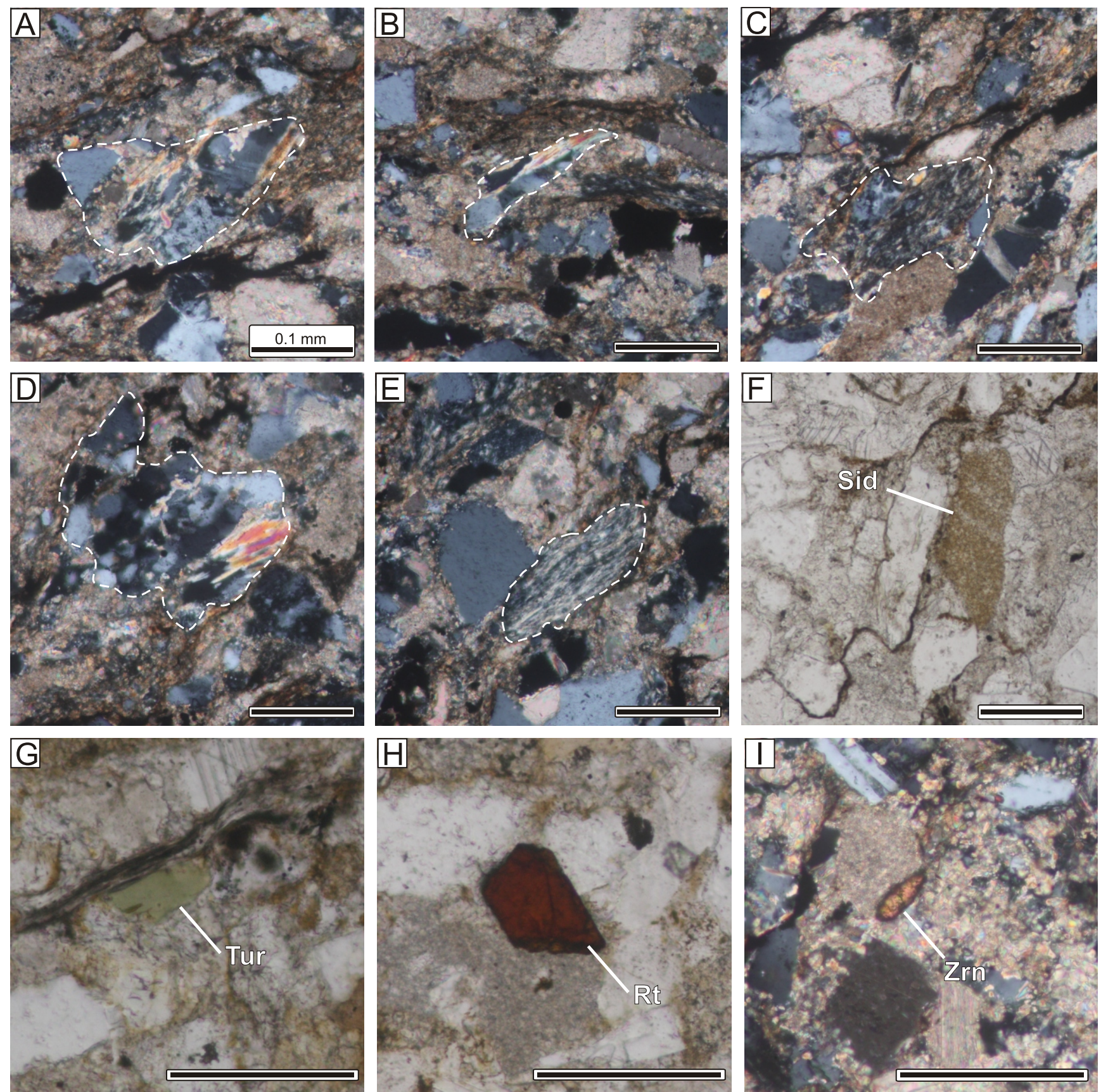

Fig. 7. Microphotographs of lithoclasts and heavy mineral grains in siltstones and sandstones from the Upper Cenomanian sediments of the Pisana Member, High-Tatric Unit, Tatra Mountains

A - gneiss lithoclast, sample Zab2/19; B - schist lithoclast, sample Zab2/19; C - hydrothermally altered granite lithoclast, sample Zab2/19; D - cataclastic granite lithoclast, sample Zab2/19; E - slate (phyllite) lithoclast, sample Zab2/19; F - siderite (Sid) lithoclast, sample Zd1; G tourmaline (Tur) grain, sample Zab4/39; H - rutile (Rt) grain, sample Zab4/39; I - zircon (Zrn) grain, sample Zd2 


\section{GEOCHEMISTRY OF SILICICLASTICS FROM SILICICLASTIC-BEARING SEDIMENTS}

\section{MAJOR AND TRACE ELEMENTS}

The geochemical composition of the sediments studied is presented in Appendix $1^{*}$, Tables 1 and 2. The siliciclastic-bearing sediments are characterized by low/medium content of $\mathrm{SiO}_{2}$ (33.6-47.7 wt.\%, average $39.6 \mathrm{wt} . \%$ ). It is related to the various amount of quartz grains in the framework and reflects the difference between sediments of the silty and sandy fractions. The content of $\mathrm{Al}_{2} \mathrm{O}_{3}$ is higher in the samples in which the enrichment in detrital quartz grains is observed (Zab3a, 6c - 14.99 and 13.79 wt.\%, respectively). High content of $\mathrm{CaO}$ (26.9 and 28.4 wt. \%, average 19.34 wt. \%) and LOI (26.6 and 26.8 wt.\%, average 20.5 wt. \%) is observed in the samples $(Z d 1,2)$ exhibiting distinctly lower content of $\mathrm{SiO}_{2}$ (33.92 and 36.49 wt.\%, respectively) and high amount of calcite cement (Figs. $6 \mathrm{G}$ and $7 \mathrm{~F}$, I). The content of $\mathrm{TiO}_{2}$ is relatively low $(0.23-0.48 \mathrm{wt} . \%$, average $0.44 \mathrm{wt} \%$ ), however, the samples which are enriched in the sandy fraction and heavy minerals (e.g., rutile) show enrichment in $\mathrm{TiO}_{2}$ (up to 0.66 wt. \%).

The major elements including $\mathrm{Al}_{2} \mathrm{O}_{3}, \mathrm{Fe}_{2} \mathrm{O}_{3}, \mathrm{TiO}_{2}$ and $\mathrm{K}_{2} \mathrm{O}$ are positively correlated with $\mathrm{SiO}_{2}$ (Fig. 8A, C-E). These correlations suggest that the distribution of these elements is controlled mainly by the occurrence of detrital minerals including micas (muscovite and biotite), chlorite and feldspars. Similar contribution, i.e. from biotite and mica-bearing metamorphic lithoclasts, is interpreted based on the positive correlations of $\mathrm{K}_{2} \mathrm{O}$ and $\mathrm{TiO}_{2}$ with $\mathrm{Al}_{2} \mathrm{O}_{3}$ (Fig. $8 \mathrm{P}, \mathrm{Q}$ ), and based on the $\mathrm{K}_{2} \mathrm{O} / \mathrm{Al}_{2} \mathrm{O}_{3}$ ratio $(0.15-0.24$; Table 2 ) that is typical of values of muscovite (Cox et al., 1995).

$\mathrm{CaO}$ shows a negative correlation with $\mathrm{SiO}_{2}$ (Fig. 8B) that is related to an influx of various amounts of carbonate cement during diagenesis and other major elements $\left(\mathrm{Al}_{2} \mathrm{O}_{3}, \mathrm{Fe}_{2} \mathrm{O}_{3}, \mathrm{TiO}_{2}-\right.$ Fig. 8J-L).

The presence of detrital minerals including biotite flakes, rutile and opaque minerals (e.g., sample Zab3a) is confirmed by the elevated content of transition metals (Ni, Co Sc, V; Appendix 1). The content of $\mathrm{Ga}$ and $\mathrm{Rb}$ (19.9 and $141.9 \mathrm{ppm}$, respectively) in the same sample provides evidence that white mica flakes and mica-bearing lithoclasts primarily control the abundance of these elements. The high contents of $\mathrm{Zr}(150.9 \mathrm{ppm})$, $\mathrm{Hf}(4.4 \mathrm{ppm})$ as well as $\Sigma \mathrm{REE}+\mathrm{Y}(171.6$ and $25.5 \mathrm{ppm}$, respectively) in sample Zab6c reflect the occurrence of heavy minerals, such as zircon and apatite. In turn, the highest contents of $\mathrm{Nb}(12.8,13.2 \mathrm{ppm})$ occur in two samples (Zab6c, 3a), including rutile grains. The concentration of LILE (Rb, Ba, Th and $\mathrm{U}$, without $\mathrm{Sr}$ ) is markedly higher in the samples enriched in the siliciclastic fraction (Zab3a, 6c, Zd11). The Sr content $(653.7-695.6 \mathrm{ppm})$ is high in the samples $(Z d) 1,2)$ enriched in carbonate cement $(\mathrm{CaO}-28.42$ and 26.86 wt. \%, and LOI 26.6 and 24.8 wt. $\%$, respectively).

Table 1

Chemical indices of the Upper Cenomanian sediments of the Pisana Member, High-Tatric Unit, Tatra Mountains

\begin{tabular}{|c|c|c|c|c|c|c|c|c|}
\hline Chemical indices & Zab3 & Zab3a & Zab6c & Zab7 & Zd1 & $\mathrm{Zd} 2$ & Zd11 & $\begin{array}{c}\text { Average } \\
(\mathrm{n}=7)\end{array}$ \\
\hline Th/Co & 0.68 & 0.80 & 0.78 & 0.59 & 0.52 & 0.53 & 0.83 & 0.68 \\
\hline $\mathrm{La} / \mathrm{Sc}$ & 2.90 & 2.17 & 2.48 & 2.23 & 2.10 & 2.24 & 2.35 & 2.35 \\
\hline $\mathrm{Th} / \mathrm{Sc}$ & 0.81 & 0.78 & 0.81 & 0.76 & 0.64 & 0.70 & 0.84 & 0.76 \\
\hline $\mathrm{Zr} / \mathrm{Sc}$ & 18.0 & 8.3 & 10.8 & 10.8 & 14.0 & 14.7 & 10.2 & 12.4 \\
\hline $\mathrm{Th} / \mathrm{Cr}$ & 0.06 & 0.12 & 0.10 & 0.12 & 0.03 & 0.05 & 0.10 & 0.08 \\
\hline $\mathrm{Th} / \mathrm{U}$ & 2.3 & 3.9 & 3.0 & 3.0 & 2.7 & 2.5 & 2.3 & 2.8 \\
\hline $\mathrm{La} / \mathrm{Th}$ & 3.56 & 2.79 & 3.04 & 2.92 & 3.28 & 3.20 & 2.82 & 3.09 \\
\hline $\mathrm{Zr} / \mathrm{Sc}$ & 18.03 & 9.29 & 10.78 & 10.83 & 14.08 & 14.68 & 10.25 & 12.56 \\
\hline $\mathrm{Fe}_{2} \mathrm{O}_{3} / \mathrm{K}_{2} \mathrm{O}$ & 3.42 & 1.61 & 2.01 & 2.15 & 5.32 & 4.23 & 1.75 & 2.93 \\
\hline $\mathrm{K}_{2} \mathrm{O} / \mathrm{Al}_{2} \mathrm{O}_{3}$ & 0.17 & 0.22 & 0.21 & 0.20 & 0.15 & 0.16 & 0.24 & 0.19 \\
\hline $\mathrm{Al}_{2} \mathrm{O}_{3} / \mathrm{TiO}_{2}$ & 18.08 & 22.71 & 21.55 & 20.88 & 16.13 & 18.13 & 22.60 & 20.01 \\
\hline SREE & 102.8 & 158.6 & 171.6 & 120.9 & 125.9 & 53.8 & 62.1 & 113.7 \\
\hline$\left(\mathrm{Eu} / \mathrm{Eu}^{*}\right)_{\mathrm{ch}}$ & 0.73 & 0.57 & 0.60 & 0.63 & 0.93 & 0.81 & 0.62 & 0.70 \\
\hline$\left(\mathrm{Eu} / \mathrm{Eu}^{*}\right)_{\mathrm{PAAS}}$ & 1.14 & 0.89 & 0.96 & 0.98 & 1.48 & 1.24 & 0.98 & 1.10 \\
\hline$\left(\mathrm{Eu} / \mathrm{Eu}^{*}\right)_{\mathrm{ucc}}$ & 1.14 & 0.89 & 0.96 & 0.98 & 1.48 & 1.24 & 0.98 & 1.10 \\
\hline$(\mathrm{La} / \mathrm{Yb})_{\mathrm{ch}}$ & 7.38 & 8.55 & 8.48 & 7.11 & 7.04 & 6.23 & 7.89 & 7.51 \\
\hline$(\mathrm{La} / \mathrm{Sm})_{\mathrm{ch}}$ & 3.04 & 3.91 & 3.47 & 3.46 & 2.72 & 2.61 & 3.78 & 3.28 \\
\hline$(\mathrm{Gd} / \mathrm{Yb})_{\mathrm{ch}}$ & 1.83 & 1.47 & 1.48 & 1.49 & 1.93 & 1.91 & 1.45 & 1.65 \\
\hline $\mathrm{ClA}$ & 67 & 76 & 74 & 69 & 66 & 68 & 72 & 70 \\
\hline PIA & 73 & 89 & 85 & 76 & 71 & 73 & 84 & 79 \\
\hline CIW & 76 & 91 & 88 & 79 & 74 & 76 & 87 & 82 \\
\hline $\begin{array}{l}\text { R ratio } \\
\left(\mathrm{SiO}_{2} / \mathrm{Al}_{2} \mathrm{O}_{3}\right)\end{array}$ & 6.2 & 3.0 & 3.4 & 4.0 & 9.1 & 8.4 & 3.1 & 5.3 \\
\hline $\mathrm{CaCO}_{3}[\%]$ & 28 & 15 & 22 & 18 & 31 & 33 & 20 & 23.9 \\
\hline
\end{tabular}

Eu anomaly $=$ Eu-normalized $/ \mathrm{Eu}^{*}$ where $\mathrm{Eu}^{*}=(\mathrm{Sm}$-normalized+Pr-normalized/2), normalized to chondrite (ch), to Post-Archean Australian Shale (PAAS), to Upper Continental Crust (UCC) 
Table 2

Average ratios of REE indices, Eu anomaly and total REE content in the Upper Cenomanian sediments of the Pisana Member, High-Tatric Unit, Tatra Mountains compared with averages in sands from modern tectonic environments

\begin{tabular}{|l|c|c|c|c|c|}
\hline & $(\mathrm{La} / \mathrm{Y})_{\mathrm{ch}}$ & $(\mathrm{La} / \mathrm{Sm})_{\mathrm{ch}}$ & $(\mathrm{Gd} / \mathrm{Yb})_{\mathrm{ch}}$ & $\mathrm{Eu} / \mathrm{Eu}$ & $\Sigma \mathrm{REE}$ \\
\hline Passive margin $^{1}$ & 9.80 & 3.67 & 1.40 & 0.74 & 107.0 \\
\hline Back-arc basin $^{1}$ & 6.50 & 2.95 & 1.30 & 0.79 & 83.6 \\
\hline Continental arc basin $^{1}$ & 7.18 & 3.19 & 1.30 & 0.76 & 113.5 \\
\hline Fore-arc basin $^{1}$ & 2.93 & 1.82 & 1.12 & 0.89 & 55.9 \\
\hline Fore-arc basin & & 5.77 & 1.61 & 0.73 & 134.0 \\
\hline High-Tatric Unit & 9.11 & 3.29 & 1.65 & 0.70 & 113.7 \\
\hline
\end{tabular}

UCC ratios from: ${ }^{1}$ - McLennan (2001) and ${ }^{2}$ - Mazur et al. (2010); shaded areas reflect similar values of indices; for other explanations see Table 1
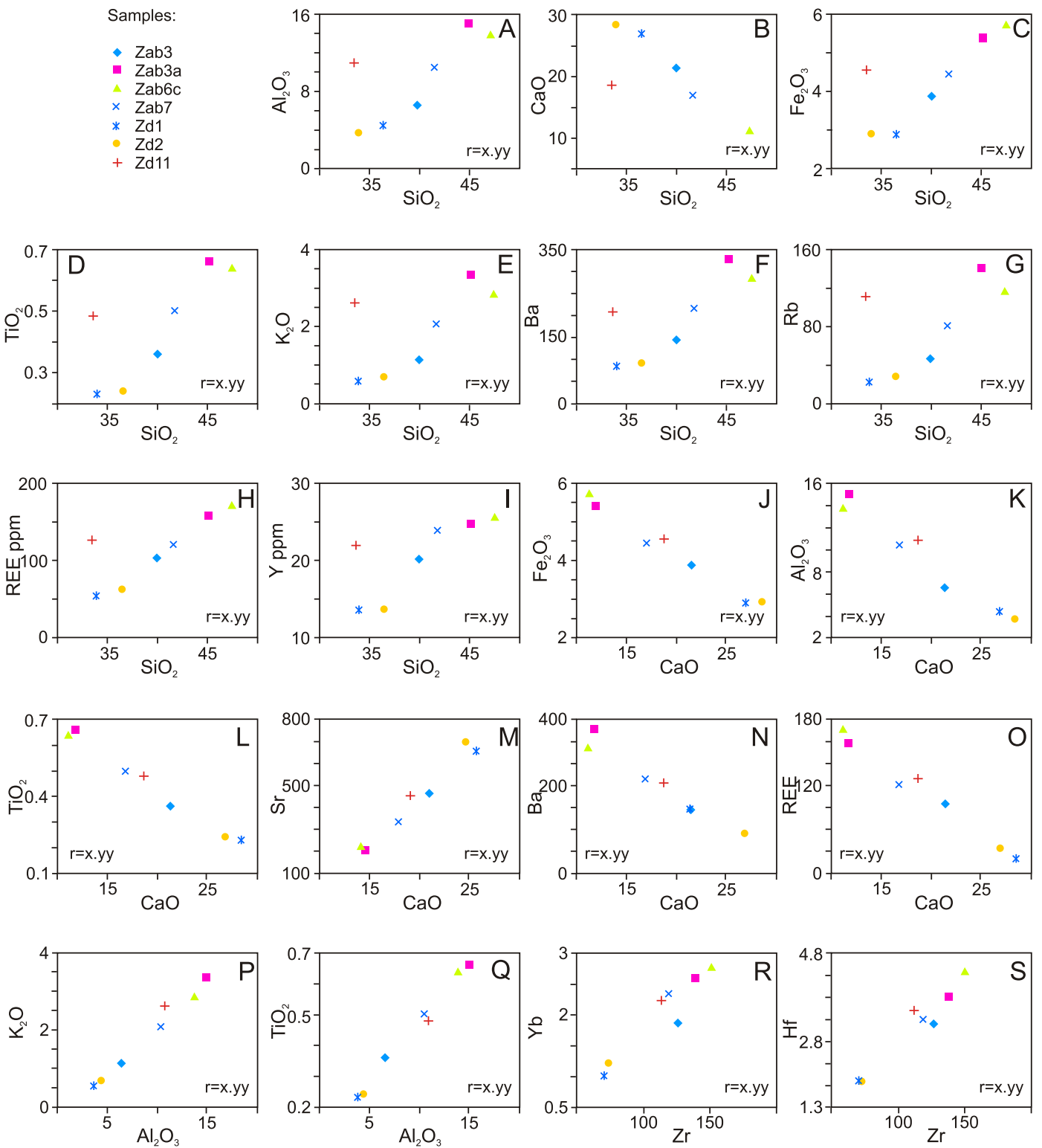

Fig. 8. Correlation diagrams between major, trace, and $\mathrm{REE}$ elements in relation to $\mathrm{SiO}_{2}, \mathrm{CaO}_{1} \mathrm{Al}_{2} \mathrm{O}_{3}$, and $\mathrm{Zr}$ from the upper Cenomanian siltstones and sandstones of the Pisana Member, High-Tatric Unit, Tatra Mountains 
The positive correlations of $\mathrm{Ba}$ and $\mathrm{Rb}$ with $\mathrm{SiO}_{2}$ (Fig. 8F, G), as well as $\mathrm{Zr}$ with $\mathrm{Yb}$ and $\mathrm{Hf}$ (Fig. $8 \mathrm{R}, \mathrm{S}$ ) show their association with heavy minerals occurring in the silty and sandy fractions of the siliciclastic sediments. Enrichment in zircon and apatite is responsible for a negative correlation of $\mathrm{Ba}$ with $\mathrm{CaO}$ (Fig. 8N, O). Among transitional elements, a positive correlation with $\mathrm{CaO}$ is exhibited only by $\mathrm{Sr}$ (Fig. 8M), indicating that $\mathrm{Ca}$ nad $\mathrm{Sr}$ were probably originally added with carbonate and/or feldspar. The significant enrichments of $\mathrm{Th}, \mathrm{Zr}, \mathrm{U}, \mathrm{Nb}$ and a high $\mathrm{Al}_{2} \mathrm{O}_{3}$ content (up to $15 \mathrm{wt} . \%$ ) are related to the occurrence of white mica (muscovite and/or illite) and heavy minerals (tourmaline, zircon and rutile) (cf. Bhatia and Crook, 1986).

The low content of $\mathrm{Zn}(121 \mathrm{ppm})$ and $\mathrm{Cu}(104.1 \mathrm{ppm})$ in sample Zab7 may reflect traces of ore-bearing mineralisation in the siliciclastic rocks. Small amount of TOT/S (up to 0.3 wt.\%) suggests the occurrence of unaltered pyrite framboids, which was confirmed by mineralogical observations (Fig. 6D, E).

Chondrite-normalized patterns of trace elements (Fig. 9A) show depletion of $\mathrm{Nb}, \mathrm{Ta}, \mathrm{P}$ and Ti elements, whereas $\mathrm{Rb}$, Th, $\mathrm{K}, \mathrm{La}, \mathrm{Ce}, \mathrm{Nd}, \mathrm{Sm}, \mathrm{Zr}$, Hf, Tb contents are elevated, compared to the chondrite values. Sr is depleted in quartz-rich sediments.

PAAS-normalized patterns of trace elements (Fig. 9B) exhibit depletion of $\mathrm{Co}, \mathrm{V}, \mathrm{Rb}, \mathrm{Ba}, \mathrm{Zr}, \mathrm{Y}, \mathrm{Hf}$, Th, $\mathrm{U}$ and Sc element. The sediments studied are markedly enriched in $\mathrm{Sr}$ and $\mathrm{Nb}$ with respect to those of PAAS. Sr is significantly enriched in carbonate-rich sediments.

UCC-normalized patterns of trace elements (Fig. 9C) reveal depletion in $\mathrm{Ba}, \mathrm{Nb}, \mathrm{Zr}$ and $\mathrm{Ti}$ and enrichment in $\mathrm{Rb}, \mathrm{Th}, \mathrm{U}, \mathrm{V}$, $\mathrm{La}, \mathrm{Ce}, \mathrm{Nd}, \mathrm{Hf}$, and $\mathrm{Sm}$. Only two samples of quartz-rich sediments (Zab 3a, 6c) are depleted in Sr. This indicates that $\mathrm{Sr}$ may be associated with calcite from the cement.

\section{RARE EARTH ELEMENTS (REE)}

The concentration of REEs is given in Appendix 1. Chondrite-normalized REE patterns are shown in Figure 9D and Table 2, and compared with the Post Archean Australian Shale (Fig. 9E and Table 1) as well as the Upper Continental Crust-normalized (Fig. 9E and Table 1) patterns (Taylor and McLennan, 1985).

In general, the REE are concentrated in fine fractions of the sediments studied (silt or clay according to Cullers et al., 1987, 1988) being accommodated in most phyllosilicates (micas), which are enriched in $\mathrm{Al}$ and Fe. Taking into account absolute concentration of REE ( $\mathrm{REE}$ ), a large variation between quartz-rich ( $\Sigma R E E=120.9-171.6 \mathrm{ppm})$ and carbonate-rich sediments $(\Sigma R E E=53.8-62.1 \mathrm{ppm})$ is observed. Chondrite-normalized REE patterns appear similar (Fig. 9D), characterized by LREE enrichment [(Lan/Smn $\left.)_{c h}=2.61-3.91\right]$ and flat pattern of HREE $\left[(\mathrm{Gdn} / \mathrm{Ybn})_{\mathrm{ch}}=1.45-1.93\right]$ with negative anomalies of Eu $\left[\left(\mathrm{Eu} / \mathrm{Eu}^{*}\right)_{\mathrm{ch}}=0.57-0.93\right]$. The samples exhibit moderate fractionation of REE (LREE/HREE) [(Lan/Ybn $\left.)_{c h}=6.23-8.55\right]$.

Despite variable concentrations of REE, their distribution patterns are similar to PAAS and UCC. The PAAS- and UCCnormalized REE values (Fig. 9E, F and Table 1) show a flat LREE pattern $\left[(\operatorname{Lan} / \mathrm{Smn})_{\mathrm{PAAS}}=0.61-0.91\right.$ and $(\mathrm{Lan} / \mathrm{Smn})_{\mathrm{UCC}}=$ $0.63-0.94]$ and slightly enhanced HREE values [ $(\mathrm{Gdn} / \mathrm{Ybn})_{\text {PAAS }}$ $=1.08-1.44$ and $\left.(\mathrm{Gdn} / \mathrm{Ybn})_{\cup c c}=1.04-1.38\right]$ with positive Eu anomalies for carbonate-rich sediments $\left(\mathrm{Eu}^{\mathrm{E}} \mathrm{Eu}^{*}\right)_{\mathrm{PAAS}}=$ $1.24-1.48$ and $(\operatorname{Lan} / Y b n) \cup C c=0.67-0.92]$. The samples display a weak fractionation of REE $\left[(\operatorname{Lan} / Y b n)_{\text {PAAS }}=0.68-0.93\right.$ and $\left.(\text { Lan/Ybn })_{\text {ucc }}=0.67-0.92\right]$

The REE, similarly as $Y$ show a positive correlation with $\mathrm{SiO}_{2}$ (Fig. $\left.8 \mathrm{H}, \mathrm{I}\right)$ providing evidence that they could be associated with the occurrence of detritic micas and feldspars in the framework. In turn, a negative correlation of REE with $\mathrm{CaO}$ (Fig. $8 \mathrm{~N}, \mathrm{O})$ may correspond to their enrichment in heavy minerals (zircon, apatite).

\section{DISCUSSION}

Siliciclastic-bearing sediments are relatively rare in the Upper Cenomanian sequence of the Pisana Member. Their total thickness is difficult to estimate due to possible tectonic repetitions, but it may contain less than one fifth of the studied succession. This material is present in laminae and thin layers in the silty and very fine-grained (up to $0.21 \mathrm{~mm}$ ) arenite fractions, being associated with carbonate grains, carbonate and siliciclastic matrix, and calcite cement. Mineral grains and lithoclasts are moderately sorted and exhibit various rounding classes, from angular through subangular to subrounded. Fraction reduction of quartz grains in the samples studied, which range from very fine sand up to silt, may be affected by transport (Folk, 1980). Exclusively small grains that are present in the sediments indicate long transport but also deposition from a weaker current than those that could carry coarser grains - absent in the studied sediments. Grain sphericity, visible in more than $40 \%$ of quartz grains in the samples is interpreted as the feature related to the source area and may indicate both long-lasted abrasion in that source area, and long river transport on the land.

\section{PARENT ROCKS COMPOSITION}

The sediments studied indicate enhanced mineralogical maturity and stability that is suggested based on their low value of the $\mathrm{Fe}_{2} \mathrm{O}_{3} / \mathrm{K}_{2} \mathrm{O}$ ratio (2.93 on average; Table 1). This ratio is related to an occurrence of minerals rich in potassium (e.g., white micas, hydromicas and K-feldspars) and with a low content of iron-bearing minerals like biotites and chlorites.

The framework of the siliciclastic sediments is dominated by quartz grains. Its optical features (mosaic and normal extinctions) show that the quartz grains are derived from felsic igneous and metamorphic rocks. Terrigenous-derived oxides $\left(\mathrm{SiO}_{2}\right.$ and $\mathrm{TiO}_{2}$ ) show a strong positive correlation with $\mathrm{Al}_{2} \mathrm{O}_{3}(\mathrm{Fig} .8 \mathrm{~A}$, $Q)$, pointing to a conclusion that siliceous organisms were insignificant in the accumulation of silica at the sea floor.

The quartz grains are accompanied by grains of feldspars, micas, chlorite, sillimanite and rare lithoclasts (Figs. 5-7). Sillimanite fibrolite aggregates, found in these sediments, could originate from medium- or high-grade metamorphic rocks (gneisses and schists). Such schists and gneisses have been described among others from the Variscan granitoids in the Central Western Carpathians (e.g., Kreutz, 1930; Burchart, 1970; Skupiński, 1975; Poller et al., 2000; Janák et al., 2001). Part of them could represent hydrothermal altered granites, based on the presence of hydrothermally altered biotite (sagenitic biotite) in the samples studied (Fig. 6K). Pebbles of such magmatic rocks are known from various sections in the Tatric and Fatric tectonic-facies units (Mišik et al., 1981).

The occurrence of igneous and metamorphic rocks in the source area is also suggested by chemical indices of the sediments. The $\mathrm{Al}_{2} \mathrm{O}_{3} / \mathrm{TiO}_{2}$ ratio ranges from 16.1 to 22.7 in the samples, the values typical of intermediate and felsic rocks (Hayashi et al., 1997). This provenance is confirmed by a low amount of $\mathrm{TiO}_{2}$ (0.44 wt.\% on average; Appendix 1), lower than in the PAAS (Taylor and McLennan, 1985) that is characteristic of more evolved (felsic) rocks. 

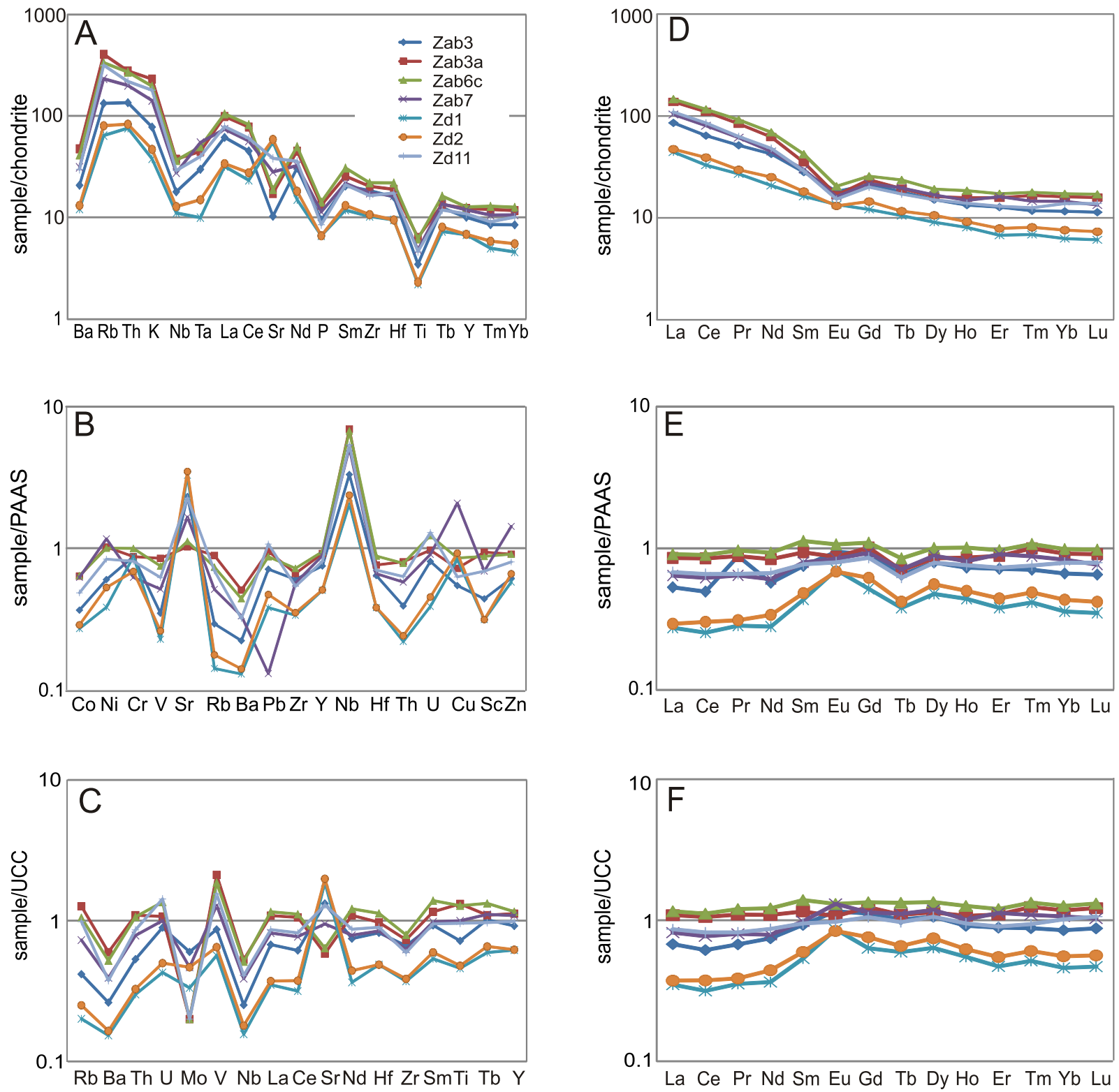

Fig. 9. Trace element and REE spider diagrams of the Upper Cenomanian siltstones and sandstones from the Pisana Member, High-Tatric Unit, Tatra Mountains

A, D - chondrite-normalized patterns (normalization data after Thompson, 1982); B, E - PAAS-normalized patterns (normalization data after Taylor and McLennan, 1985); C, F - UCC-normalized patterns (normalization data after Taylor and McLennan, 1985)

The ratios between relatively immobile trace elements, including La/Sc, Th/Sc, Th/Co and Th/Cr, are also considered suitable indicators of parent rock provenance (e.g., Wronkiewicz and Condie, 1990; Cox et al., 1995; Cullers, 1995; Cai et al., 2011; Ali et al., 2014). This is supported by the fact that $\mathrm{La}$, Th and $\mathrm{Hf}$ are enriched in felsic rocks, whereas $\mathrm{Co}, \mathrm{Cr}$, and Sc are more concentrated in mafic rocks. In the present study, these ratios (Table 1) are not significantly different from those of the MCS or PAAS, suggested to have been derived from granitoid sources (Taylor and McLennan, 1985; Cullers, 1994, 2000, 2002). In the discrimination diagrams (after Floyd and Leveridge, 1987) that show relations between immobile trace elements and trace elements characteristic of felsic rocks (Fig. 10A, B), the sediments studied generally plot in the field of felsic or silicic rocks. Similar origin of terrigenous material is suggested by the U/Th ratio ( 2.8 on aver- age; Table 1) that is close to values of felsic rocks (Larsen and Gottfried, 1960), and significantly lower with respect to sedimentary rocks (Bhatia and Taylor, 1981).

The REE patterns of the parent rocks are preserved in clastics showing differences in fractionation of REE and Eu anomaly values (Taylor and McLennan, 1985; Hanson, 1989; McLennan, 1989). The mafic rocks have low $\Sigma$ LREE/ $\Sigma$ HREE ratios with little or no Eu anomalies, whereas felsic rocks usually contain higher $\Sigma$ LREE/ $\Sigma$ HREE ratios and negative Eu anomalies (e.g., Cullers and Graf, 1984; Cullers, 1994). The sediments studied exhibit moderate fractionation of REE (LREE/HREE) $\left[(\operatorname{Lan} / \mathrm{Ybn})_{\mathrm{ch}}=6.23-8.55\right]$, similar to that of PAAS, enhanced by the LREE enrichment and almost flat HREE (Fig. 9D). They also display a moderate negative $\left(\mathrm{Eu}^{\mathrm{E}} \mathrm{Eu}^{*}\right)_{\mathrm{ch}}$ anomaly (Table 1$)$. These data also support felsic parent rocks for the sediments. 
Summing up, all these petrographic data and chemical indices show that the sediments are derived from moderately fractionated felsic igneous rocks and their metamorphic counterparts (gneisses and shists).

\section{WEATHERING AND RECYCLING PROCESSES}

Relationships between alkali and alkaline earth elements are used in the interpretation of chemical weathering history of the sediments (Nesbitt and Young, 1982, 1984). This involves the degradation of feldspars that leads to the loss of $\mathrm{Ca}, \mathrm{Na}$ and $\mathrm{K}$. The intensity of chemical weathering could be measured by using various indices: the Chemical Index of Alteration (CIA), according to Nesbitt and Young (1982), the Plagioclase Index of Alteration (PIA) after Fedo et al. (1995), the Chemical Index of Weathering (CIW) after Harnois (1988), and the Ruxton ratio (R) after Ruxton (1968).
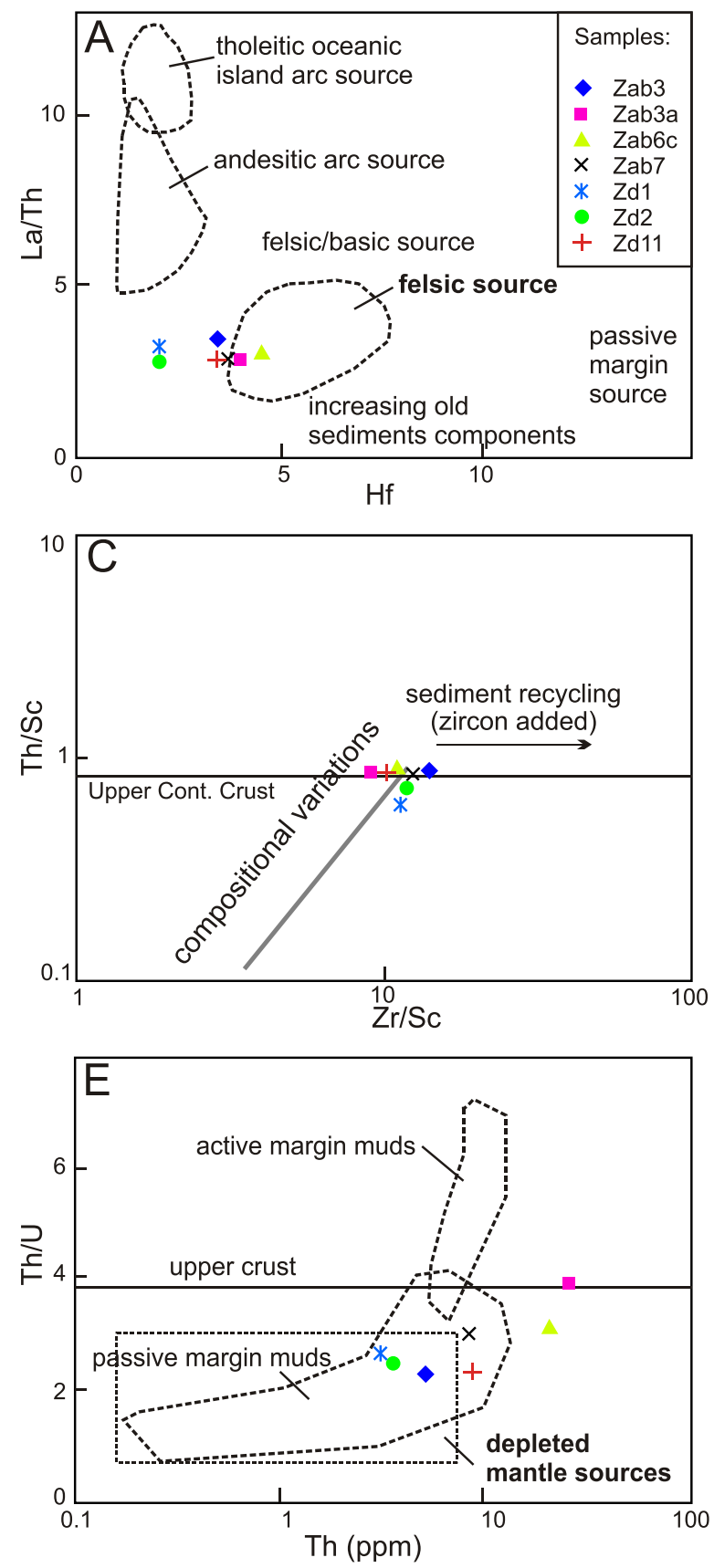

The CIA expresses the degree weathering of feldspars to clays, defined as $\mathrm{CIA}=\left[\mathrm{Al}_{2} \mathrm{O}_{3} /\left(\mathrm{Al}_{2} \mathrm{O}_{3}+\mathrm{CaO} *+\mathrm{Na}_{2} \mathrm{O}+\mathrm{K}_{2} \mathrm{O}\right)\right]$ $\times 100$, where the $\mathrm{CaO}^{*}$ refers to $\mathrm{CaO}$ in silicates only. The PIA expresses weathering of plagioclase to clays, defined as $\mathrm{PIA}=$ $\left[\left(\mathrm{Al}_{2} \mathrm{O}_{3}-\mathrm{K}_{2} \mathrm{O}\right) /\left(\mathrm{Al}_{2} \mathrm{O}_{3}+\mathrm{CaO}^{*}+\mathrm{Na}_{2} \mathrm{O}-\mathrm{K}_{2} \mathrm{O}\right)\right] \times 100$. The CIW, named as the potassium-free index, is defined as $\mathrm{CIW}=$ $\left[\mathrm{Al}_{2} \mathrm{O}_{3} /\left(\mathrm{Al}_{2} \mathrm{O}_{3}+\mathrm{CaO}+\mathrm{Na}_{2} \mathrm{O}\right)\right] \times 100$. The $\mathrm{R}$ is a very simply index given by the $\mathrm{SiO}_{2} / \mathrm{Al}_{2} \mathrm{O}_{3}$ ratio, assuming that $\mathrm{Al}_{2} \mathrm{O}_{3}$ remains immobile during weathering, so that changes in $\mathrm{R}$ reflect silica loss as a proxy for total element loss. Unfortunately, the relatively high amounts of carbonates in the samples, confirmed by Scheibler analyses in the Zabijak Gully section $\left(\mathrm{CaCO}_{3}\right.$ ranges from 15 to $28 \%$; Table 1) create the problems in application of the weathering indices, related to separation of $\mathrm{Ca}$ that may come from both carbonates and silicates. Nevertheless, we calculated the values of $\mathrm{CaO}^{*}$ by assuming that the concentration of this oxide is equal to that of $\mathrm{Na}_{2} \mathrm{O}$, as proposed by McLennan (1993) and Bock et al. (1998). The calculated values of weath-
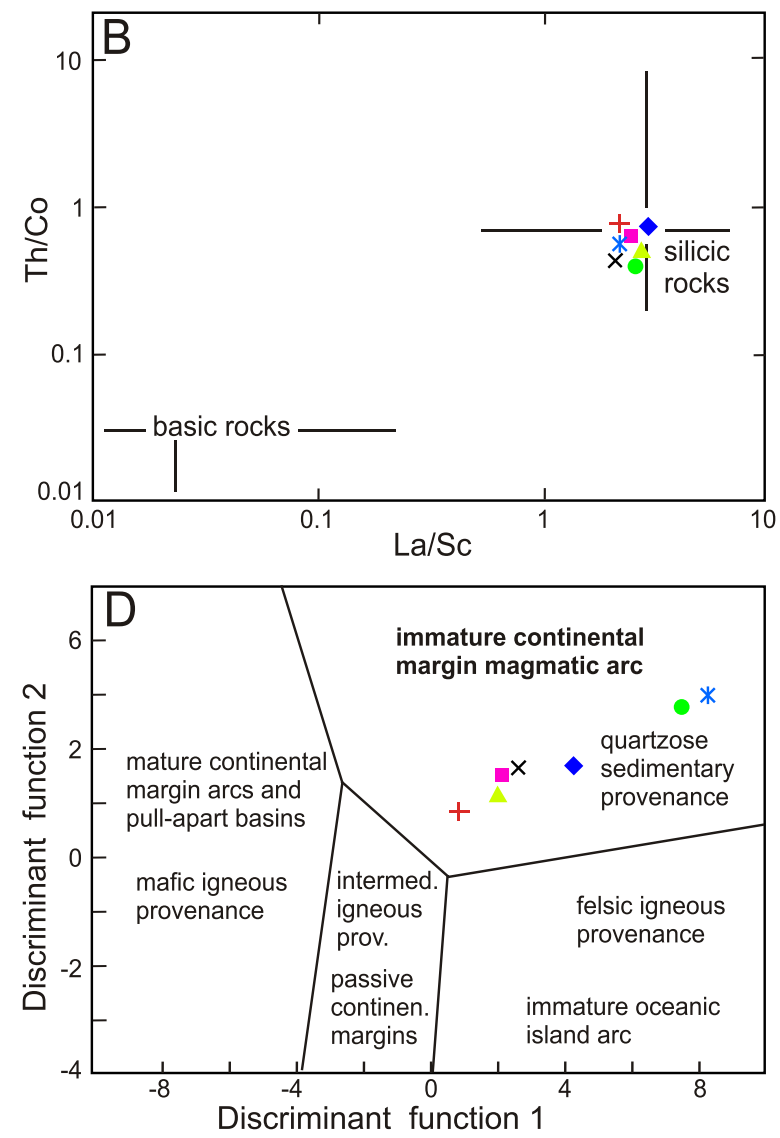

Fig. 10. Discrimination diagrams of the Upper Cenomanian siltstones and sandstones from the Pisana Member, High-Tatric Unit, Tatra Mountains

A - Th/Sc versus $\mathrm{Zr} / \mathrm{Sc}$ diagram after McLennan et al. (1993); B - discriminant function 1-2 diagram after Roser and Korsch (1988); C - plot of La/Th versus $\mathrm{Hf}$ after Floyd and Leveridge (1987); D - Th/U versus Th diagram after McLennan et al. (1993); E - Th/Co versus La/Sc diagram after Cullers (2002) 
ering indices are relatively high (Table 1 ): $\mathrm{ClA}=70 \%$ on average, $\mathrm{PIA}=79 \%$ on average, $\mathrm{CIW}=81 \%$ on average, and the $\mathrm{R}$ $=5.3$ on average, indicating moderate to intense chemical weathering processes of rocks at the source area.

The $\mathrm{Zr} / \mathrm{Sc}$ ratio is an indicator of zircon abundance (e.g., McLennan et al., 1993), and thus it is considered as a good indicator of sediment recycling. This ratio is relatively low in the sediments studied, ranging between 9.27 and 18.03 (Table 1). In turn, a positive correlation between $\mathrm{Th} / \mathrm{Sc}$ and $\mathrm{Zr} / \mathrm{Sc}$ corresponds to non-recycled sediments, while a more rapid increase in $\mathrm{Zr} / \mathrm{Sc}$ (zircon enrichment) than in $\mathrm{Th} / \mathrm{Sc}$ is typical of recycled sediments (McLennan et al., 1993). The data presented on Figure $10 \mathrm{C}$ show relatively high $\mathrm{Th} / \mathrm{Sc}(0.76$ on average) and low $\mathrm{Zr} / \mathrm{Sc}$ ratios (12.56 on average) in the sediments studied, which is interpreted as a minor (or lack of) sediment recycling and sorting expressed by zircon enrichments. Furthermore, a low amount of $\mathrm{TiO}_{2}$ (0.44 wt.\% on average; Appendix 1) and low amount of REE (113.7 ppm on average; Table 2) compared to UCC values (146 ppm; McLennan, 1989) do not confirm enrichment in heavy minerals.

Microfacies analyses show segregation of minerals in the studied material, depending on the fraction. Fine and very fine sandstones are rich in quartz and lithic grains, while mudrocks are exclusively rich in micas (Figs. 4B and 6J). Mica flakes are usually easily winnowed from arenites or they are hydraulically sorted (e.g., Folk, 1980), and originate mostly during weathering processes. Thus, the abundant micas in fine-grained sediments may indicate stronger winnowing of light, small particles during a period of more arid climate in land environments. Successive transport of redeposited material for a long distance took place in a low-energy environment. Such environments are deltas or sluggish rivers which deposited fluvial sands or deltaic sediments far from the source area (Folk, 1980). Farther dislocation of fine sediments took place on the shelf due to seasonal water circulation, like in modern marine environments. Among the examples of such environment is the San Pedro Shelf along the California Coast (e.g., Drake and Cacchione, 1985), where weak tide-generated bottom currents maintain material in the silt and clay fractions in suspension above the bottom and transport it offshore toward the outer shelf. This material may be settled during periods of declining current velocity under the threshold value during periods of seasonal water circulation change. The weak currents can transport silt and clay material, while the sand fraction was moved during strong storm events (e.g., Ferré et al., 2005).

\section{TECTONIC SETTING}

The major and trace element chemical compositions of sedimentary rocks can be used to discriminate tectonic settings of sedimentary basins (Bhatia and Crook, 1986; Roser and Korsch, 1986, 1988; McLennan et al., 1993). Based on the binary discrimination diagram of Roser and Korsch (1986), the parent rocks of the sediments studied are derived from "immature continental margin magmatic arc" (Fig. 10D). As illustrated in the trian-
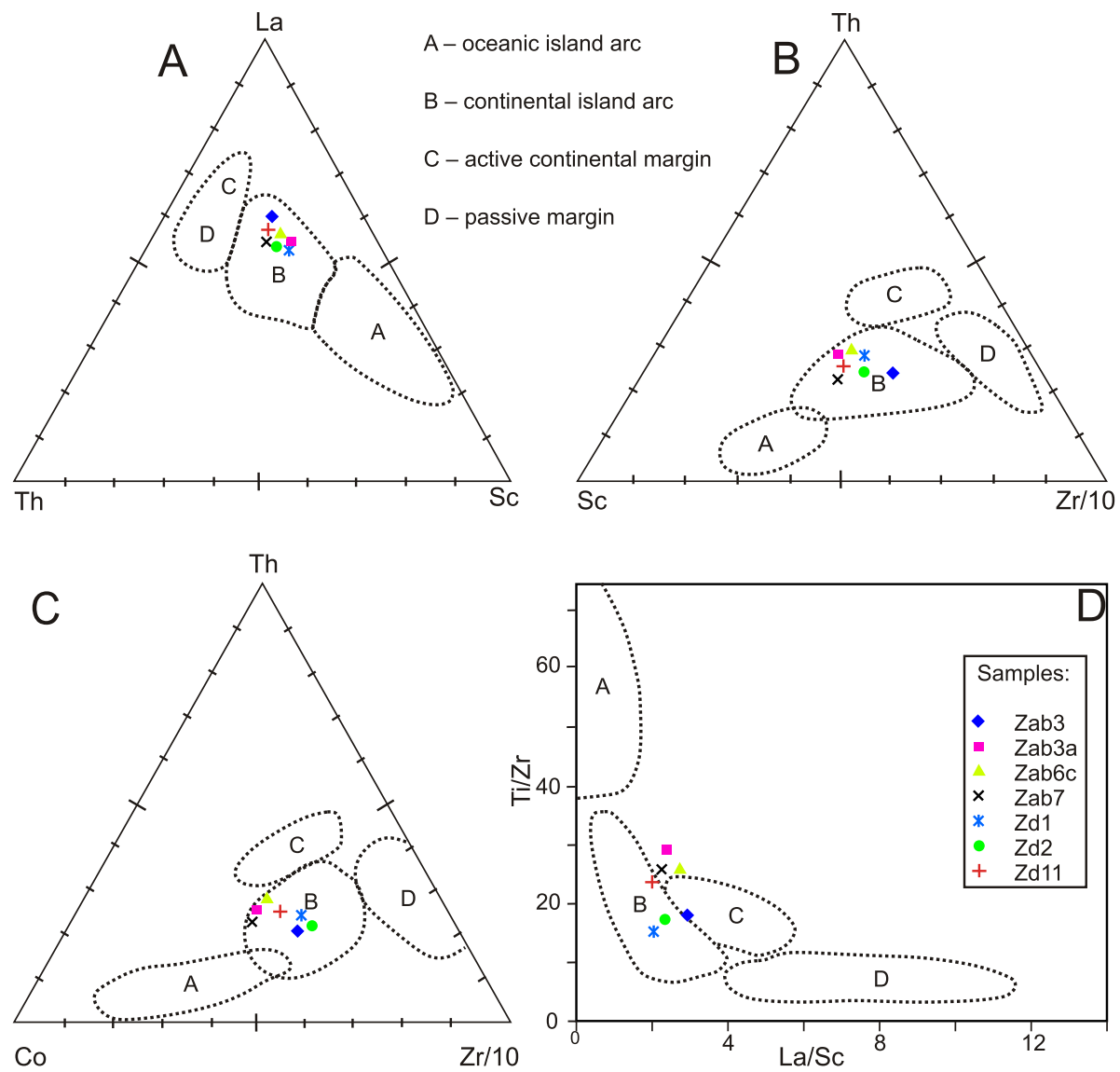

Fig. 11. Ternary and rectangular diagrams of trace elements from the Upper Cenomanian siltstones and sandstones in the Pisana Member, High-Tatric Unit, Tatra Mountains diagrams after Bhatia and Crook (1986) 
gular diagram La/Th-Sc (Fig. 11A), proposed by Bhatia and Crook (1986), the sediments are plotted in the field related to "continental island arc". Furthemore, in the Th-Sc-Zr/10 ternary diagram (Fig. 11B) of tectonic setting discrimination (Bhatia and Crook, 1986), all of the data are plotted inside the field corresponding to "active continental margin". Similar tectonic discrimination is suggested on the Th-Co-Zr/10 triangular diagram (Fig. 11C), where all samples plot inside the "active continental margin" field (Bhatia and Crook, 1986).

The sediments display a low $T h / U$ ratio and low $U$ abundance (Table 1 and Appendix 1), which is characteristic of modern sediments originated from depleted mantle sources of arc provenance in active margin settings (Fig. 10E), as was suggested by Mc Lennan et al. (1993). The average ratios of REE indices (Eu anomaly and $\Sigma$ REE; Table 2) in the sediments are typical of averages in sands from modern continental arc basins (McLennan, 2001).

\section{CONCLUSIONS}

The petrographic and chemical compositions of the Upper Cenomanian siliciclastic sediments of the Pisana Member (Zabijak Formation) in the Tatric area show variability of siliciclatic material supplied to the Zliechov (Križna) marine basin. In the source area, this material was transported by rivers flowing through the crystalline massifs, built of felsic rocks, most probably containing various types of granitoids and low-, medium- or high-grade metamorphic rocks (schists and gneisses). Such in- terpretation is based on petrographic analysis and have been confirmed by the chemistry and geochemical characteristics, where trace elements, especially the immobile elements, such as REE, Th, $\mathrm{Cr}$, Co, $\mathrm{Zr}$, and $\mathrm{Y}$, were used as the indices for sediment provenance.

Geochemical weathering indices (CIA, PIA, CIW, R) suggest that the material transported to the marine environment was moderately or even intensely chemically altered. Mineral grains and lithoclasts in the distal marine facies (Pisana Member) are moderately sorted, and the grains exhibit various rounding classes. Geochemical indices related to sorting processes (low $\mathrm{Zr} / \mathrm{Sc}$ ratio, low amount of $\mathrm{TiO}_{2}$ and $\mathrm{REE}$ ) confirmed the microscopic observations, excluding the enrichment in heavy minerals (zircon, tourmaline, rutile; Fig. 7G-I), thus the recycling of this material has a minor significance.

The small differences in chemical composition of the sediments are related to their fractions, thus they result from sorting processes during their transport and deposition at the basin floor. The type and the fractions of grains, and general maturity of siliciclastic-bearing sediments may indicate their derivation and long distance from source areas. Microfacies analyses showing fraction-dependent segregation of minerals in the studied material suggest transport of redeposited material over a long distance in a low-energy environment. First, it was a transport in deltas of sluggish rivers, followed by farther dislocation of fine sediments on the shelf, related to seasonal water circulation. The transport of this fine-grained particles was also likely in diluted turbidites, as was suggested earlier by Krajewski (2003). In such sense, this siliciclastic material has a "synorogenic" character, representing the distal facies of diluted turbidites (Fig. 12) coming

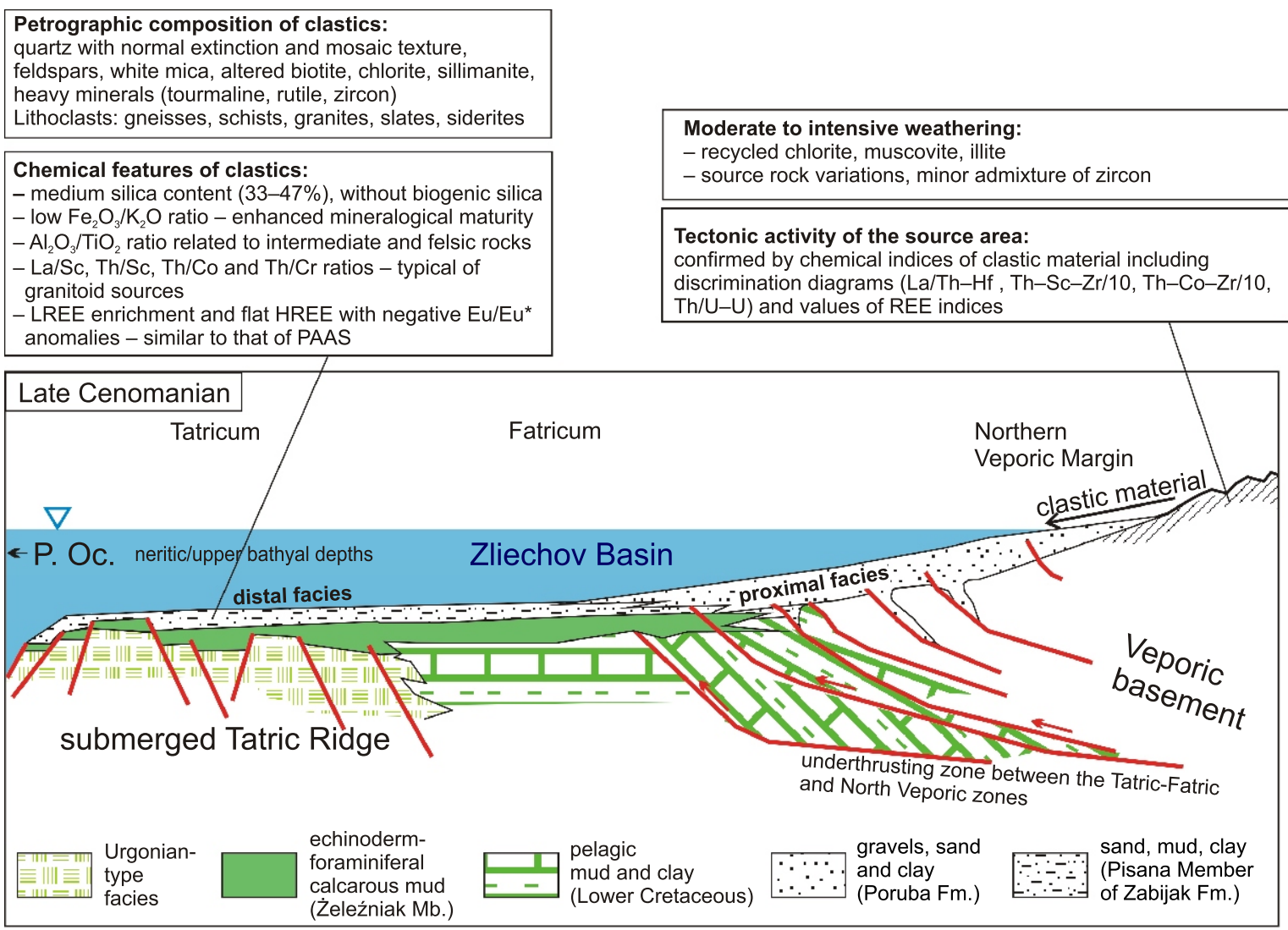

Fig. 12. Model with petrographic and geochemical features of the Late Cenomanian siliciclastic sedimentation in the Zliechov (Križna) Basin, northward of the underthrusting zone between the Tatric-Fatric and Veporic sedimentary areas model based on Plašienka, 2012 (supplemented by Bąk et al., 2016) 
from the shelf edge of the active northern Veporic margin, where the Tatric-Fatric basement, including various Lower Cretaceous carbonate sediments at the top, was underthrusted below the Veporic basement (e.g., Michalik, 2007; Prokešová et al., 2012; Plasienka, 2012). The proximal facies are represented by the Poruba Formation that consists of thicker clastic material containing bodies of exotic-bearing conglomerates (Mišik et al., 1981; Häusler et al., 1993).

The low siliciclastic input observed upward the section might be associated with diminishing of the source area composed of felsic and metamorphic rocks and with stepwise inland progradation of a carbonate platform, caused by a sea level rise during the Late Cenomanian (Bak et al., 2016). The upward-decreasing content of siliciclastic grains may also indicate a climate influence, and a change from a humid climate with higher precipitation and stronger leaching of particles to a more arid climate with stronger winnowing of light, small mica flakes.

Acknowledgements. The study was supported by the National Science Centre to K. Bak (grant 2011/01/B/ST10/07405), and by the Ministry of Science and Higher Education to M. Bak (Project DS-AGH University of Science and Technology, WGGiOS-KGOiG No. 11.11.140.173). The authors are grateful to three reviewers, O. Leitnerova, P. Łuczyński and J. Michalik for their helpful remarks. Thanks also go to T.M. Peryt for useful editorial corrections. Special thanks go to K. Leszczyński for improving the English text.

\section{REFERENCES}

Ali, S., Stattegger, K., Garbe-Schönberg, D., Frank, M., Kraft, S., Kuhnt, W., 2014. The provenance of Cretaceous to Quaternary sediments in the Tarfaya basin, SW Morocco: evidence from trace element geochemistry and radiogenic $\mathrm{Nd}-\mathrm{Sr}$ isotopes. Journal of African Earth Sciences, 90: 64-76.

Bac-Moszaszwili, M., Burchart, J., Głazek, J., Iwanow, A., Jaroszewski, W., Kotański, Z., Lefeld, J., Mastella, L., Ozimkowski, W., Roniewicz, P., Skupiński, A., Westwalewicz-Mogilska, E., 1979. Geological Map of the Polish Tatra, scale 1:30,000. Wyd. Geol., Warszawa.

Bak, K., Bak, M., 2013. Late Albian through Cenomanian foraminiferal assemblage from the youngest deposits of Tatra Mountains, Central Western Carpathians; biostratigraphical and palaeoecological aspects. Acta Geologica Polonica, 63: 223-237.

Bak, K., Bak, M., Dulemba, P., Okoński, S., 2016. Late Cenomanian environmental conditions at the submerged Tatric Ridge, Central Western Carpathians during the period preceding Oceanic Anoxic Event 2 - a palaeontological and isotopic approach. Cretaceous Research, 63: 95-112.

Bhatia, M.R., Crook, K.A.W., 1986. Trace elements characteristics of graywackes and tectonic setting discrimination of sedimentary basins. Contribution of Mineralogy and Petrology, 92: 181-193.

Bhatia, M.R., Taylor, S.R., 1981. Trace element geochemistry and sedimentary provinces: a study from the Tasman Geosyncline, Australia. Chemical Geology, 33: 115-125.

Bock, B., McLennan, S.M., Hanson, G.N., 1998. Geochemistry and provenance of the Middle Ordovician Austin Glen Member (Normanskill Formation) and the Taconian Orogeny in New England. Sedimentology, 45: 635-655.

Burchart, J., 1970. Rocks of the Goryczkowa "Crystalline Island" in the Tatra Mountains (in Polish with English summary). Studia Geologica Polonica, 32: 5-183.

Cai, G., Guo, F., Liu, X., Sui, S., 2011. Elemental and Sr-Nd isotopic compositions of Cenozoic sedimentary rocks from the Dongying Sag of Jiyang depression, North China: implications for provenance evolution. Geochemical Journal, 45: 33-55.

Cox, R., Low, D.R., Cullers, R.L., 1995. The influence of sediment recycling and basement composition on evolution of mudrock chemistry in the southwestern United States. Geochimica et Cosmochimica Acta, 59: 2919-2940.

Cullers, R.L., 1994. The controls of major and trace element variation of shales, siltstones, and sandstones of Pennsylvanian-Permian age from uplifted continental blocks in Colorado to platform in Kansas, USA. Geochimica et Cosmochimica Acta, 58: 4955-4972

Cullers, R.L., 1995. The controls on the major and trace element evolution of shales, siltstones and sandstones of Ordovician to
Tertiary age in the Wet Mountain region, Colorado, USA. Chemical Geology, 123: 107-131.

Cullers, R.L., 2000. The geochemistry of shales, siltstones and sandstones of Pennsylvanian-Permian age, Colorado, USA: implications for provenance and metamorphic studies. Lithos, 51: 181-203.

Cullers, R.L., 2002. Implications of elemental concentrations for provenance, redox conditions, and metamorphic studies of shales and limestones near Pueblo, CO, USA. Chemical Geology, 191: 305-327.

Cullers, R.L., Graf, J., 1983. Rare earth elements in igneous rocks of the continental crust: intermediate and silicic rocks, ore petrogenesis. In: Rare-Earth Geochemistry (ed. P. Henderson): 275-312. Elsevier, Amsterdam.

Cullers, R.L., Barrett, T., Carlson, R., Robinson, B., 1987. REE mineralogic changes in Holocene soil and stream sediment. Chemical Geology, 63: 275-297.

Cullers, R.L., Basu, A., Suttner, L.J., 1988. Geochemical signature of provenance in sand-material in soils and stream sediments near the Tobacco Root Batholith, Montana, USA. Chemical Geology, 70: 335-348

Decker, J., Helmold, K.P., 1985. The effect of grain size on detrital modes: a test of the Gazzi-Dickinson point-counting method discussion. Journal of Sedimentary Petrology, 55: 618-620.

Dickinson, W.R., 1985. Interpreting provenance relations from detrital modes of sandstones. NATO ASI Series C, Mathematical and Physical Sciences, 148: 333-363.

Drake, D.E., Cacchione, D.A., 1985. Bottom currents and sediment transport on San Pedro Shelf, California. Journal of Sedimentary Research, 55: 15-28.

Fedo, C.M., Eriksson, K., Krogstad, E.J., 1996. Geochemistry of shale from the Archean ( 3.0Ga) Buhwa Greenstone belt, Zimbabwe. Implications for provenance and source area weathering. Geochimica et Cosmochimica Acta, 60: 1751-1763.

Ferré, B., Guizien, K., Durrieu de Madron, X., Palanques, A., Guillén, J., Grémare, A., 2005. Fine-grained sediment dynamics during a strong storm event in the inner-shelf of the Gulf of Lion (NW Mediterranean). Continental Shelf Research 25: 2410-2427.

Floyd, P.A., Leveridge, B.E., 1987. Tectonic environment of the Devonian Gramscatho basin, south Cornwall: framework mode and geochemical evidence from turbiditic sandstones. Journal of the Geological Society, 144: 531-542.

Folk, R.L., 1951. A comparison chart for visual percentage estimation. Journal of Sedimentary Petrology, 21: 32-33.

Folk, R.L., 1980. Petrology of Sedimentary Rocks. Austin, Texas, Hemphill. 
Hanson, G.N., 1989. An approach to trace element modeling using a simple igneous system as an example. Reviews of Mineralogy and Geochemistry, 21: 79-97.

Haq, B.U., 2014. Cretaceous eustasy revisited. Global and Planetary Change, 113: 44-58.

Harnois, L., 1988. The CIW index: a new chemical index of weathering. Sedimentary Geology, 55: 319-322.

Häusler, H., Plašienka, D., Polák, M., 1993. Comparison of Mesozoic successions of the Central Eastern Alps and the Central West Carpathians. Jahrbuch der Geologischen Bundesanstalt, 136: 715-739.

Hayashi, K., Fujisawa, H., Holland, H., Ohmoto, H., 1997. Geochemistry of $\sim 1.9 \mathrm{Ga}$ sedimentary rocks from northeastern Labrador, Canada. Geochimica et Cosmochimica Acta, 61 4115-4137.

Ingersoll, R.V., Bulard, T.F., Ford, R.L., Grimn, J.P., Pickle, J.P., Sares, S.W., 1984. The effect of grain size on detrital modes: a text of the Gazzi-Dickinson Point Counting method. Journal of Sedimentary Petrology, 54: 103-116.

Janák, M., Plašienka, D., Frey, M., Cosca, M., Schmidt, S.T., Lupták, B., Méres, Š., 2001. Cretaceous evolution of a metamorphic core complex, the Veporic unit, Western Carpathians (Slovakia): $\mathrm{P}-\mathrm{T}$ conditions and in situ ${ }^{40} \mathrm{Ar} /{ }^{39} \mathrm{Ar}$ UV laser probe dating of metapelites. Journal of Metamorphic Geology, 19: 197-216.

Jurewicz, E., 2005. Geodynamic evolution of the Tatra Mts. and the Pieniny Klippen Belt (Western Carpathians): problems and comments. Acta Geologica Polonica, 55: 295-338.

Krajewski, K., 2003. Facies development and lithostratigraphy of the Hightatric mid-Cretaceous (Zabijak Formation) in the Polish Tatra Mountains. Studia Geologica Polonica, 121: 81-158.

Kreutz, S., 1930. O tatrzańskim trzonie krystalicznym (in Polish). Wierchy, 8: 60-82.

Larsen, E.S., Gottfried, D., 1960. Uranium and thorium in selected suites of igneous rocks. American Journal of Science, 258A: 151-169.

Lefeld, J., 1985. Jurassic and Cretaceous lithostratigraphic units of the Tatra Mountains. Studia Geologica Polonica, 84: 1-93.

Mazur, S., Aleksandrowski, P., Turniak, K., Krzemiński, L., Mastalerz, K., Górecka-Nowak, A., Kurowski, L., Krzywiec, P., Żelaźniewicz, A., Fanning, M.C., 2010. Uplift and late orogenic deformation of the Central European Variscan belt as revealed by sediment provenance and structural record in the Carboniferous foreland basin of western Poland. International Journal of Earth Sciences, 99: 47-64.

McLennan, S.M., 1989. Rare earth elements in sedimentary rocks: influence of provenance and sedimentary processes. Reviews of Mineralogy and Geochemistry, 21: 169-200.

McLennan, S.M., 1993. Weathering and global denudation. Journal of Geology, 101: 295-303.

McLennan, S.M., 2001. Relationships between the trace element composition of sedimentary rocks and upper continental crust. Geochemistry, Geophysics, Geosystems, 2 (4) doi: 10.1029/2000GC000109

McLennan, S.M., Hemming, S., McDaniel, D.K., Hanson, G.N., 1993. Geochemical approaches to sedimentation, provenance and tectonics. GSA Special Paper, 284: 21-40.

Michalík, J., 2007. Sedimentary rock record and microfacies indicators of the latest Triassic to mid-Cretaceous tensional development of the Zliechov Basin (Central Western Carpathians). Geologica Carpathica, 58: 443-453.

Mišik, M., Jablonsky, J., Mock, R., Sykora, M., 1981. Konglomerate mit exotischen Material in dem Alb der Zentralen Westkarpaten-paläographische und tektonische Interpretation.
Acta Geologica et Geographica Universitatis Comenianae, Geologica, 37: 5-55.

Nesbitt, H.W., Young, G.M., 1982. Early Proterozoic climates and plate motions inferred from major element chemistry of lutites. Nature, 199: 715-717.

Nesbitt, H.W., Young, G.M., 1984. Prediction of some weathering trends of plutonic and volcanic rocks based on thermodynamic and kinetic considerations. Geochimica at Cosmochimica Acta, 48: 1523-1534.

Passendorfer, E., 1930. Étude stratigraphique et paléontologique du Crétacé de la série hauttatrique dans les Tatras (in Polish with French summary). Prace Państwowego Instytutu Geologicznego, 2: 351-676.

Passendorfer, E., 1978. Jak Powstały Tatry (in Polish). Wyd. Geol., Warszawa.

Plašienka, D., 1999. Tectochronology and paleotectonic model of the Jurassic-Cretaceous evolution of the Central Western Carpathians (in Slovak with English summary). Veda, Bratislava.

Plašienka, D., 2003. Development of basement-involved fold and thrust structures exemplified by the Tatric-Fatric-Veporic nappe system of the Western Carpathians (Slovakia). Geodinamica Acta, 16: 21-38.

Plašienka, D., 2012. Jurassic syn-rift and Cretaceous syn-orogenic, coarse-grained deposits related to opening and closure of the Vahic (South Penninic) Ocean in the Western Carpathians - an overview. Geological Quarterly, 56 (4): 601-628.

Poller, U., Janak, M., Kohút, M., Todt, W., 2000. Early Variscan magmatism in the Western Carpathians: U-Pb zircon data from granitoids and orthogneisses of the Tatra Mountains (Slovakia). International Journal of Earth Sciences, 89: 336-349.

Prokešová, R., Plašienka, D., Milovský, R., 2012. Structural pattern and emplacement mechanisms of the Krížna cover nappe (Central Western Carpathians). Geologica Carpathica, 63: 13-32.

Roser, B.P., Korsch, R.J., 1986. Determination of tectonic setting of sandstone-mudstone suites using $\mathrm{SiO}_{2}$ content and $\mathrm{K}_{2} \mathrm{O} / \mathrm{Na}_{2} \mathrm{O}$ ratio. Journal of Geology, 94: 635-650.

Roser, B.P., Korsch, R.J., 1988. Provenance signatures of sandstone-mudstone suites determining using discriminant function analysis of major-element data. Chemical Geology, 67: 119-139.

Ruxton, B.P., 1968. Measures of the degree of chemical weathering of rocks. Journal of Geology, 76: 518-527.

Skupiński, A., 1975. Petrogenesis and structure of the crystalline core between Ornak and Rohacz, Western Tatra Mts. (in Polish with English summary). Studia Geologica Polonica, 49: 4-105.

Taylor, S.R., McLennan, S.M., 1985. The Continental Crust: its Composition and Evolution. Blackwell, Oxford.

Terry, R.D., Chilingar, G.V., 1955. Summary of "Concerning some additional aids in studying sedimentary formations" by M.S. Shvetsov. Journal of Sedimentary Petrology, 25: 229-234.

Thompson, R.N., 1982. Magmatism of the British Tertiary volcanic province. Scottisch Journal of Geology, 18: 49-107.

Vašíček, Z., Michalík, J., Reháková, D., 1994. Early Cretaceous stratigraphy, paleogeography and life in Western Carpathians. Beringeria, 10: 5-168.

Voigt, S., Wagreich, M., Surlyk, F., Walaszczyk, I., Uličný, D., Čech, S., Voigt, T., Wiese, F., Wilmsen, M., Michalík, J., Jagt, J.W.M., Felder, P.J., Schulp, A.S., 2008. Cretaceous. In: The Geology of Central Europe, 2: Mesozoic and Cenozoic (ed. T. McCann): 923-997. Geological Society Book, London.

Wronkiewicz, D.J., Condie, K.C., 1990. Geochmistry and mineralogy of sediments from the Ventersdorp and Transvaal Supergroups South Africa: cratonic evolution during the Early Proterozoic. Geochimica et Cosmochimica Acta, 54: 343-354. 